\title{
ŽENSKÉ A DETSKÉ HROBY S HONOSNÝM ŠPERKOM V DLHOM 9. STOROČÍ V ČECHÁCH, NA MORAVE A NA SLOVENSKU (Komparácia, identifikácia elít a pokus o novú historickú interpretáciu formovania vel’komoravského Nitrianska)
}

\section{Hana Chorvátová* - Matej Harvát**}

*Centrum medievistických studií,Jilská 1, 11000 Praha 1, chorvatova@gmail.com

**Historický ustav SAV, Klemensova 19, 81109 Bratislava, histhary@savba.sk

\begin{abstract}
Women and Children Burials with Luxurious Jewelry in the Long $9^{\text {th }}$ Century in Bohemia, Moravia and Slovakia (Comparision, Identification of Elite and an Attempt for the New Historical Interpretation of Formation of Great Moravian Territory of Nitra). The study primarily deals with the archeological findings of the women and children luxurious jewelry from the burial sites located at regions nort of the Danube of the so-called Great Moravia. The paper consists of two parts - surveys of archeological and textual evidence. The main goal is interdisciplinary evaluation and comparison of available and well-known sources which indicate a specific discrepancy in the general historiographic interpretation of the formation of the Great Moravian „state“. The discrepancy between archeological and historiographic interpretation is much more obvious in the case of the so-called Principality of Nitra and its assumed elite. The first part of the study contains a comparative analysis of the findings of luxurious jewelry from the regions of present-day Bohemia, Moravia and western Slovakia, where authors point out the qualitative and quantitative differences in the spatial distribution of these artifacts. In the second part, the authors propose the alternative explanatory model of the formation of the so-called core area of Great Moravia based on the different reading of some notorious textual evidence. In this section is critically examined a conventional and rather problematic historiographic explanation based on the notion of the unification of (old) Moravian principality and „Nitrava“ principality as a consequence of the expulsion of Priwina from Nitra by the Moravian dux Mojmír I around 833. Contrastingly, authors rather suggest the later incorporation of the Nitra region to the political unit ruled by the Moravian prince which may have happend as a result of Svätopluk expansion.
\end{abstract}

Keywords: luxurious jewelry, Great Moravia, Early Medieval burial-grounds, social stratification, Territory of Nitra

Abstrakt: Štúdia sa primárne zaoberá nálezmi ženského a detského luxusného šperku z pohrebísk nachádzajúcich sa na naddunajských územiach, ktoré počas 9. storočia tvorili súčast' (tzv.) Velkej Moravy. Text tvoria dve časti, ktorých spoločnou snahou je interdisciplinárne porovnanie archeologických poznatkov s historickou interpretáciou prameňov písomných, pochádzajúcich z raného aj mladšieho stredoveku. Nové relatívno-chronologické sekvencie šperku spolu s jeho predpokladaným absolútnym datovaním poskytujú d’alšie možnosti historického výkladu. Ciel’om je poukázat' na určitý rozpor medzi všeobecne prijímanou interpretáciou písomných prameňov a výsledkami archeologického bádania, a to predovšetkým v otázke vzniku Vel'kej Moravy. Nesúlad vystupuje do popredia najmä v súvislosti s územím predpokladaného Nitrianskeho kniežatstva a jeho elít. Prvá čast' komparatívne analyzuje výsledky archeologických výskumov pohrebísk z územia stredných Čiech, Moravy a Slovenska vo vzt’ahu k fenoménu honosného šperku v 9. storočí, pričom poukazuje na kvantitatívne a kvalitatívne odlišnosti v rozšírení týchto predmetov na sledovaných územiach. $V$ druhej časti je ponúknutý alternatívny výkladový model formovania politicko-teritoriálneho „jadra“ Velkej Moravy. V protiklade k tradičnému a dosial' neproblematizovanému výkladu, ktorý postuluje spojenie Moravského a Nitrianskeho kniežatstva za Mojmíra I. po vyhnaní Pribinu, autori uvažujú až o neskoršom začlenení regiónu na východ od Váhu do územného a politického celku ovládaného mojmírovským kniežat’om, ktoré sa mohlo udiat’ až v súvislosti s výbojmi Svätopluka.

Kl’účové slová: honosný šperk, Vel’ká Morava, ranostredoveké pohrebiská, sociálna stratifikácia, Nitriansko 
https://doi.org/10.46283/musarch.2020.1.04

\section{1. Úvod}

Pozoruhodné nálezy bohatého honosného šperku z územia južnej Moravy sú už niekol'ko desat'ročí dôležitou témou v archeologickom bádaní (Hrubý 1955; Dostál 1965, 1991; Galuška 1996, 2013; Ungerman 2005, 2018). Prvou otázkou, ktorú archeologické bádanie dlhodobo rieši, je chronológia honosného šperku. Bez poznania chronologického vymedzenia archeologického materiálu nie je možné pokračovat' $v$ d’alších aspektoch výskumu, ako sú perspektívy kultúrno-historickej interpretácie (Stener 1968, 24-25). Podrobný výskum honosného šperku môže prinášat' riešenia otázok mocenských vplyvov, stratifikácie spoločnosti a sociálnej dynamiky, hospodárskeho vzostupu i úpadku a tiež i formovania identity (Pobl 2010; Cooper - Al-Saad 2015).

Vel'mi dlhé obdobie bol ranostredoveký honosný šperk z územia južnej Moravy, označovaný ako byzantsko-orientálny (Niederle 1933, Hrubý 1955, 229) alebo veligradský (Dostál 1965; Galuška 1996, 92), pričom spoločne s d’alšími nálezmi zo stredného Podunajska bývali datované prevažne do záveru 9. a prvej polovice 10. storočia (Hrubý 1955, 229, obr, 41, 310; Dostál 1966, 44). Od devät'desiatych rokov sa ustálil názor, podla ktorého najintenzívnejší výskyt šperku spadal do druhej polovice 9. až po začiatok 10. storočia (Dostál 1991). ${ }^{1}$ Zároveň boli rozličné typy náušníc a tzv. gombíkov vnímané ako takmer jednoliata masa bez vnútorného vývoja. Z toho vyplývala aj pomerne jednoznačná historická interpretácia šírenia a používania týchto ženských okrás, klasifikovaných ako šperk Vel’kej Moravy. Honosný šperk bol zvyčajne chápaný ako jedna z konzekvencií byzantskej misie Konštantína a Metoda, s ktorými na Moravu prichádzali i byzantskí klenotníci (Štefanovičová 1989, 138; Dostál 1991, 84). Zároveň boli bohaté ženské hroby pre niektorých bádatel’ov dôkazom mocenského a najmä hospodárskeho vzostupu Velkej Moravy za vlády Rastislava a Svätopluka (Dostál 1966, 90). Aj v minulosti i v súčasnosti sa bádatelia zhodujú v interpretácii, že honosné kolekcie náušníc a tzv. gombíkov patrili nobilite (Scbránil 1925, 180; Klanica 1970, 424; Pavlovičová 1996, 99; Profantová - Kavánová 2003, 68; Chorvátová 2009).

Posledné desat'ročia priniesli odlišný pohl'ad na datovanie a vývoj honosného šperku. Zmena sa týka najmä zistení k relatívno-chronologickému vývoju ženských okrás (najmä Chorvátová 2004; Ungerman 2005; Galuška 2013). Spolu s novými zisteniami k relatívnej chronológii šperku došlo i k prehodnoteniu absolútneho datovania. V súčasnosti sa prijíma datovanie honosného šperku už do prvej polovice 9. storočia (Ungerman 2005, 729; Galuška 2013, 196-241), ale nie sú úplne vylúčené aj možnosti datovania niektorých typov náušníc a gombíkov už do záveru 8. storočia (Chorvátová 2007, 2015). Rozdielne názory na absolútne datovanie vyplývajú i z odlišného pohl’adu na vnútorný vývoj honosného šperku. Š. Ungerman a L. Galuška uvažujú len o dvoch fázach vývoja okrás. Približne polovica 9. storočia je považovaná za zlom, kedy sa niektoré typy strácajú a objavujú nové. Obaja autori sa vo svojich prácach venovali skôr staršiemu horizontu šperku, len L. Galuška naznačil náplň mladšieho horizontu (Ungerman 2005; Galuška 2013, 250-251). Mladším horizontom ženských okrás sa venoval kolektív autorov pod vedením J. Macháčka (Macháček Dresler - Přchystalová 2019). Autorka uvedených riadkov predstavila trojetapový vývin ženského honosného šperku (Chorvátová 2007, 89-96; 2015, 148-176), ktorý je aj podkladom pre historicko-kultúrny výklad v predloženej štúdii.

Nové pohlady na relatívne a absolútne datovanie šperku otvárajú aj nové perspektívy kultúrno-historickej interpretácie významu a rozšírenia týchto predmetov. Štúdia sa bude venovat’ porovnaniu intenzity zastúpenia ženského honosného šperku, konkrétne zlatých a strieborných náušníc a tzv. gombíkov - na pohrebiskách z dlhého 9. storočia ${ }^{2}$ V Čechách ${ }^{3}$, na Morave a Slovensku. V texte sa pokúsime zhodnotit’ a interpretovat’ výsledky komparácie publikovaných nálezov.

\footnotetext{
1 Podrobný vývoj názorov na datovanie šperku a vývoj terminológie spracovala autorka týchto riadkov vo svojej štúdii (Chorvátová 2004, 199-209) a naposledy aj Š. Ungerman $(2018,511-514)$.

2 Pojem „dlhé 9. storočie“ sa začína objavovat’ častejšie v archeologickej literatúre venujúcej sa práve tomuto obdobiu. Niektoré javy, ktoré sa naplno rozvinuli v 9. storočí, sa začali objavovat’ v závere 8. storočia a vytrácajú sa v prvých desat'ročiach 10 . storočia. Nedávno sa úvahy o „dlhom 9 . storočí objavili i na archeologickej konferencii v Budapešti v decembri 2015, jej názov znel: How long is the 9th century A. D. in the Carpathian Basin? New Data - New Approaches. Pozri Takács 2018.

3 V príspevku rozumieme pod termínom Čechy predovšetkým územie stredných Čiech.
} 


\section{Tri horizonty honosného ženského šperku ${ }^{4}$}

Pod honosným šperkom rozumieme rôzne druhy zlatých a strieborných náušníc a tzv. gombíkov, ktoré vytvárajú svojimi kombináciami v hrobových inventároch rôzne kolekcie. Na základe analýzy vzájomných kombinácií alebo absencií nie je vylúčená možnost’ rozlíšit’ v chronológii ženského honosného šperku tri horizonty (obr. 1).

Predpokladaný najstarší horizont (obr. 1: A) je zatial zastúpený výraznými kolekciami najmä na pohrebiskách v priestore Uherského Hradiště ako Uherské Hradište-Sady (Galuškea 1990), zo Starého Města sú známe dve polohy Na valách (Hrubý 1955) a Špitálky (Poulike. 1955). Uvedený horizont predstavujú najmä náušnice zdobené na hornom oblúku, niektoré typy lunicových náušníc a niekol’ko typov gombíkov. Kolekcie najstarších typov šperku vychádzajú z klenotníckych tradícií Byzancie a Avarského kaganátu (Eisner 1947; Szókee 1992, 862). Šperk daného horizontu je zhotovený najmä zo zlata. Na ostatných pohrebiskách významných centier ako napr. Mikulčice (Poulík 1957; Profantová - Kavánová 2003; Klanica - Kavánová - Kourül-Ungerman 2019) a Břeclav-Pohansko (Kalousek 1971; Machácée - Dresler - Př́chystalová - Sladek 2016) daný horizont nie je zastúpený s takou intenzitou ako v priestore Uherského Hradiště. Objavujú sa len jednotlivé náušnice (1-2 ks). Rovnako nie je takmer vôbec zaznamenaný ani na tzv. vel'komoravských pohrebiskách z územia Slovenska. Náušnice zdobené na hornom oblúku v bronzovom prevedení sa objavujú i na juhozápadnom Slovensku, ale len na pohrebiskách patriacich do avarského kultúrneho okruhu, napr. Nové Zámky (Čilinská 1960), Želovce (Čilinská 1973), Holiare (Toč̉e 1968) a iné. Absolútne datovanie najstaršieho horizontu hrobov s honosným šperkom na južnej Morave je možné na podklade doterajších znalostí vymedzit’ posledným desat'ročím 8. storočia a prvými desat'ročiami 9. storočia (Chorvátová 2007, 97; 2015, 152-158). Pri chronologickom určení je možné vychádzat' z datovania náušníc zdobených na hornom oblúku, ktoré sa objavujú na pohrebiskách z obdobia avarského kaganátu - typ IX a najmä X (Čilinskáa 1975, 79-80). Uvedený typ náušníc doznieva práve v danom období, neskôr sa už v materiálnej kultúre neobjavujú. Staršie datovanie do záveru 9. storočia (Hrubý 1955, $235,236)$ vychádzalo z nesprávnej premisy v datovaní podla malty, čo viedlo následne $\mathrm{k}$ nesprávnemu určeniu relatívnej chronológie na pohrebisku Na valách v Starom Městě (Chorvátová 2004). Dnes je uvedené datovanie opustené a bádatelia sa prikláňajú $\mathrm{k}$ chronologickému vymedzeniu najstaršieho horizontu šperku prelomom 8. a začiatkom 9. storočia (Ungerman 2005, 715). Uvedené datovania podporujú i nálezy mincí s typologicky obdobnými náušnicami zo ženského hrobu z chorvátskej lokality Trilj. Súčasné chorvátske bádanie datuje hrob do širšieho časového horizontu do záveru 8. až prvej tretiny 9. storočia a do hrobov vložené mince cisára Konštantína V. (741 - 775) a jeho syna považuje za spolahlivý datovací prostriedok nielen v prípade pohrebiska Trilj, ale i Biskupija-Crkvina a d’alších lokalít, ktoré boli objavené neskôr (Jurčevič 2011, 136). V súčasnosti je chorvátskymi archeológmi odmietaná téza J. Wernera o minciach Konštantína V. ako rodinnej zbierke, ktorá sa mala uchovávat' v rodine niekol'ko generácií (Werner 1978/1979, 237). ${ }^{5}$ Chorvátski bádatelia predpokladajú, že nálezy, ktoré sprevádzajú mince Konštantína V. a jeho syna, spadajú do záveru 8. až prvej tretiny 9. storočia (Jurčevič 2011, 138; Petrinec 2019, 40) a opierajú sa aj o výsledky rádiokarbónovej analýzy z hrobu $18 \mathrm{v}$ Livade pri Konjsko polje s kalibrovaným časovým rozpätím rokov 768 - 896 (Petrinec 2019, 38-40). Nezávislé prírodovedné datovanie v prípade moravských nálezov zatial' chýba. V hrobe č. 193/51 z pohrebiska Na valách zo Starého Města s nálezmi náušníc zdobenými na hornom oblúku bol nájdený drevený sarkofág pozostávajúci z dvoch kmeňov stromu. Ak by existovala šanca využit' daný nález na získanie nezávislého dendrodatovania, bolo by to len a len prínosom do súčasnej diskusie o absolútnom datovaní ženského honosného šperku na južnej Morave. ${ }^{6}$

\footnotetext{
4 Predkladaná štúdia sa opiera o výsledky, ktoré už boli publikované (Chorvátová 2004, 2007) a o dizertačnú prácu, ktorá sa podrobnejšie venovala problému vývoja a datovania honosného šperku (Chorvátová 2015). Autori by sa na tomto mieste chceli pod’akovat' recenzentom za kritické a konštruktívne pripomienky. Zohl’adnenie ich komentárov nám pomohlo postavit’ niektoré z predložených záverov, dúfame, na o niečo pevnejšiu pôdu.

5 J. Werner úplne vylúčil možnost' datovat' nálezy z Trilje a Biskupije-Crkviny do konca 8. storočia. Nálezy považoval za rodinný poklad a mali v hroboch slúžit' ako obol mŕtvych. Opieral sa pritom o prácu E. Kolníkovej o obole mŕtvych (Kolníková 1967). E. Kolníková pritom pracovala s nálezmi arpádovských mincí. Taktiež J. Werner vychádzal z chronológie V. Hrubého, ktorá bola zat’ažená nesprávnym určením relatívnej chronológie na pohrebisku Staré Město - Na valách. Uvedená skutočnost’ má dodnes vplyv pri analýzach a interpretáciách nálezov z Biskupije-Crkviny u nemeckých bádatel’ov. Pri argumentácii o datovaní nálezov z Biskupije-Crkviny do druhej štvrtiny 9. storočia sa opierajú o práce slovenských archeológov, ktorí však akceptovali a d’alej rozvíjali Hrubého chronológiu ostrôh; napr. J. Kleemann sa odvoláva na práce D. Bialekovej (1977) a A. Ruttkaya (1970) (Kleemann 2010, 86, pozn. 63).

6 Hrob č. 193/51 bol prevrstvený mladšími hrobmi 194/51 a 195/51 a nachádzajú sa v severnej časti staroměstského pohrebiska Na valách. Mladší hrob 195/51 obsahoval mozaikový korálik a Š. Ungerman $(2005,741)$ ho zaradil medzi hroby tzv. predköttlašského horizontu. O chronologickom vymedzení daného horizontu Š. Ungerman uviedol: „Pokud jde o prínos analyzovaných typư ženského šperku pro absolutni datováni poćatků velkomoravského kostrového pobrbiváni, spadá tato żmèna ritu někam do doby prèdköttlašskébo horizontu, který je nově kladen do 4. čtvrtiny 8. století. Tím sice neni dosud uvádèné datum „keolem roku 800 “
} 
Druhý horizont kolekcií predstavujú úplne nové formy náušníc a gombíkov, ktoré sa doposial' na sledovanom území nevyskytovali, môžeme preto hovorit’ o novej vlne šperku (obr. 1: B, C). Sú to rôzne formy košíčkových, bubienkových, stĺpčekých náušníc, náušníc s klasovitým hrozienkom a najmä gombíky s rytou výzdobou najčastejšie s palmetami. V kolekciách daného šperku môžeme rozlíšit’ dve etapy, pričom mladšiu máme doloženú i stratigraficky, napr. na pohrebisku v Starom Měste Na valách (Chorvátová 2007, 89-94) alebo na pohrebisku pri druhom mikulčickom kostole, hroby č. 44 (Poulík 1957, 292-330, obr. 75). Hroby so šperkami novej vlny sú známe aj z územia Čiech a dnešného Slovenska. Podl’a nedávnych výskumov je analogický šperk novej vlny pomerne bohato zastúpený i na nekropole Zalavár-Vársziget v niekdajšom sídle Pribinu a jeho syna Kocel’a (Szóke 2010, Abb.: 16). Pri datovaní novej vlny šperku je situácia ešte komplikovanejšia. Chýba relevantný nález mince alebo nezávislého prírodovedného datovania. Podl'a pozorovaní z horizontálnej stratigrafie na pohrebisku v Starom Měste Na valách je možné predpokladat', že nová vlna šperku sa na južnej Morave začala prejavovat' niekedy ešte počas prítomnosti najstaršieho horizontu kolekcí ženského honosného šperku, čiže niekedy v priebehu prvej tretiny až polovice 9. storočia. Daný predpoklad vychádza z nálezovej situácie hrobov 282/49 a 279/49. Uvedené hroby sa nachádzajú v priamej vertikálnej stratigrafii. Hrob č 279/49 padá do hrobu č. 282/49 (Hrubý 1955, 455). Oba hroby sa nachádzajú v štvorci 7/D, čiže priamo nadväzujú na najstarší horizont hrobov na pohrebisku zo štvorcov 7/B a 7/C. Hrob č. 279/49 bol s vel'kou pravdepodobnost'ou uložený po istom čase, nakol'ko sa prepadával do hrobu č. 282/49 s híbkou 265 cm. Hrob č. 282/49 obsahoval najbohatšiu kolekciu ženského šperku akú doteraz asi poznáme (obr. 1:13). V hrobe č. 279/49 s híbkou $170 \mathrm{~cm}$ sa našiel len jeden artefakt kostená píšt’alka - frčák (Hrubý 1955, 455). Analogický predmet sa vyskytol aj na pohrebisku Pobedim II v polohe Na laze v hrobe č. 26 (Vendtová 1969, 181). Na pohrebisku sa v hrobe č. 94 (Vendtová 1969, 189) objavili ostrohy typu IA podl’a V. Hrubého alebo typ 9 podl'a Z. Robaka $(2013,34)$. V súčasnosti sa uvedený typ ostrôh datuje do priebehu druhej polovice 9. storočia a začiatku 10. storočia (Robak 2013, 35). Pohrebisko v Pobedime II v polohe Na lazoch s píšt’alkou je možné na základe terajších poznatkov datovat' do priebehu druhej polovice 9. storočia. Na staroměstskom pohrebisku Na valách sa nepredpokladá ani v súčasnosti pokračovanie pochovávania hlboko do 10. storočia (Galuška 2013, 251). Z toho vyplýva, že hrob č. 279/49 musel byt' uložený najneskôr niekedy na začiatku 10. storočia. Nevieme, aký dlhý čas ubehol medzi uložením hrobu 282/49 a 279/49, ale vzhl’adom k tomu, že hrob nebol rešpektovaný, nie je možné predpokladat' krátky časový úsek. Tiež hrob č. 282/49 plynulo nadväzoval na hroby najstaršieho horizontu. Ďalšou indíciou pre datovanie novej vlny už do priebehu prvej polovice 9. storočia je nálezová situácia hrobov č. 65, 63 a 38 z pohrebiska Břeclav-Pohansko pri kostole. Skupina hrobov, spolu s d’alšími hrobmi 58 a 37, sa nachádza 8,2 m severozápadne od západného rohu kostola v priestore severného rohu staršieho palisádového opevnenia dvorca. Nové zhodnotenie nálezovej situácie preukázalo, že hrob č. 38 neprekrýva žl’ab po staršej palisáde (Kalousek 1971, 44), ale hroby 65 a 38 boli zahíbené z danej skupiny hrobov ako prvé (Košta - Hošek - Macháček - Dresler - Príchystalová 2019, 187). V hrobe č. 65 bol objavený meč, ktorý podl’a poslednej analýzy kombinuje znaky mečov podl'a Petersenovej typológie typ B a H (Košta-Hošek - Macháček - Dresler - Prüchystalová 2019, 197). Záver autorov článku je: „Meč z brobu H 65 predstavuje ve

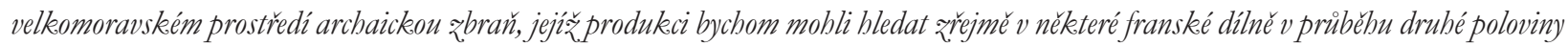
8. nebo ve starši cásti 9. století. Stratigrafická situace i radiokarbonová metoda umožnuji datovat jeho uloženi do hrobu ve starši etapé vývoje velmožskébo dvorce, a to s jistotou někedy v pribébu 9. stoleti." (Košta - Hošek - Macháček - Dresler - Prüchystalová 2019, 201). Autori sa opierajú pri datovaní o radiokarbónovú analýzu, ktorá má pre hrob 65 hodnoty 694 - 746 (16,0 \%), 763 889 (79,4 \%), 695 - 700 (0,6 \%), 710 - 745 (10,8 \%), 764 - 891 (83,9\%) (Košta - Hošek - Macháček - Dresler - Príchystalová 2019, 189, tab. 1) a ktorá teda dovol'uje vážnejšie uvažovat' aj o priebehu prvej polovice 9. storočia. Vzhl'adom k získaným údajom autori uvažujú len o priebehu celého 9. storočia, čo však pre vývoj materiálnej kultúry 9. storočia je vel’mi široký interval. Súčasné bádanie ponúka niekol'ko indícií, ktoré podporujú úvahy už o prvej polovici 9. storočia. Silný argument ponúkajú dve pohrebiská: Staré Město Na valách a pohrebisko pri II. mikulčickom kostole. Na oboch nekropolách archeologický výskum zachytil dva horizonty hrobov. Jedna stratigrafická situácia na pohrebisku Na valách je opísaná vyššie, d’alšie sú v štvorcoch 7 - 10/C - E alebo aj v štvorcoch 2 - 3/C (Hrubý 1955, plán č. 3;

zásadně zpochybnèno, nicménè archeologicky definovaný horizont a jeho synchronizace s vívojem karolinské hmotné kultury prèdstavuji prece jen "pevnèjš puidu pod nohama“, než tradični datování, které bylo v prvé radè výsledkem historických úvah o dalekosáblých zmènách ve strédním Podunají po válkách Karla Velikého s Avary." Ak teda hrob 195/51 je zaradený do predköttlašského horizontu, kam možno v absolútnom datovaní zaradit’ starší hrob hrob č. 193/51? Nielen vzhl'adom k tejto nálezovej situácii ale aj k nálezovej situácii d’alších hrobov (33/48 a 181/49) je otázne, či predköttlašský horizont skutočne predchádza horizont hrobov s honosným šperkom. Skôr sa javí, že hroby so šperkami, ktoré sa prisudzujú predköttlašskému horizontu sú súčasné s najstaršími hrobmi s honosným šperkom ako sú napr. 193/51, 200/51 alebo 122/51 (Chorvátová 2015, 28-29). 


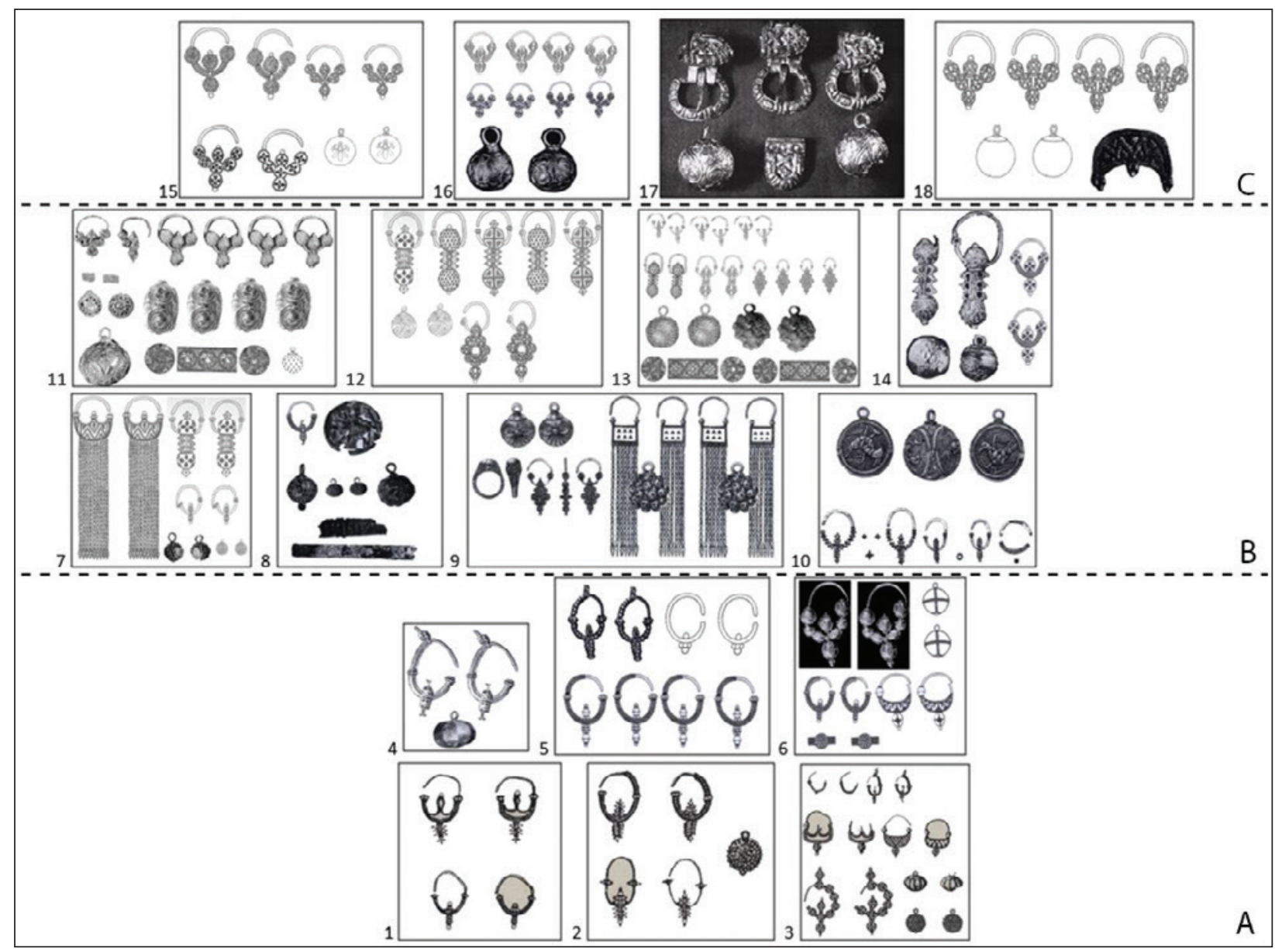

Obr. 1. A - Najstarší horizont honosného šperku, datovanie koniec 8. a začiatok 9. storočia po prvú tretinu 9. storočia (?), A 1 - Uherské Hradiště-Sady (d’alej UH-Sady) - hrob č. 87/60; 2 - UH-Sady, hrob č. 86/60; 3 - UH-Sady, hrob č. 209/59, (podl’a Galuška 1990); 4 - Staré Město „Na valách“ (d’alej SM) - hrob č. 51/50; 5 - SM, hrob č. 200/51; 6 - SM, hrob č. 193/51 (podl’a Hrubý 1955).

B - „Nová vlna šperku“ po začiatku 9. storočia približne, horná hranica nie je zatial” presne stanovená, B 7 - SM, hrob č. 106/AZ (podl’a Hruby 1955); 8 - SM-Špitálky, hrob č. 15 (podl’a Poulík 1955); 9 - Břeclav-Pohansko

(d’alej BP), hrob č. 158; 10 - BP, hrob č. 38 (podl'a Kalousek 1971); 11 - SM, hrob č. 251/49; 12 - SM, hrob č. 317/49; 13 - SM, hrob č. 282/49; 14 - SM, hrob č. 299/49 (podl'a Hrubý 1955).

C - Mladší horizont „,novej vlny šperku“ niekedy po druhej polovici 9. storočia zistené aj na poklade archeologickej situácie, C 15 - SM, hrob č. 15/48; 16 - SM, hrob č. 5/48 (podl’a Hruby 1955); 17 - Mikulčice, II. kostol - hrob č. 44; 18 - Mikulčice, II. kostol, hrob č. 1 (podl’a Poulike 1957, schématizované obrázky náušníc podl'a Dostál 1960).

Fig. 1. A - The earliest horizon of luxurious jewelry, dated to end of $8^{\text {th }}$ Century and from early to first third of $9^{\text {th }}$ Century (?), A 1 - Uherské Hradiště-Sady (next UH-Sady) - grave n. 87/60; 2 - UH-Sady, grave n. 86/60; 3 - UH-Sady, grave n. 209/59, (after Galuškea 1996); 4 - Staré Město „Na valách“ (next SM) - grave n. 51/50; 5 - SM, grave n. 200/51; 6 - SM, grave n. 193/51 (after Hrubý 1955).

B - „New wave of jewelery“ after early $9^{\text {th }}$ Century, upper timeline is not yet specified, B 7 - SM, grave n. 106/AZ (after Hrubý 1955); 8 - SM-Špitálky, grave n. 15 (after Poulík 1955); 9 - Břeclav-Pohansko (after BP), grave n. 158; 10 - BP, grave n. 38 (after Kalousek 1971); 11 - SM, grave n. 251/49; 12 - SM, grave n. 317/49; 13 - SM, grave n. 282/49; 14 - SM, grave n. 299/49 (after Hruby 1955).

C - Later horizon of „New wave of jewelery" after the second half of the $9^{\text {th }}$ century, also found on the basis of archaeol. finding situation, C 15 - SM, grave n. 15/48; 16 - SM, grave n. 5/48 (after Hrubj 1955);

17 - Mikulčice, II. church - grave n. 44; 18 - Mikulčice, II. church, grave n. 1 (after Poulík 1957, rings after Dostál 1960). 
Chorvátová 2007, 89-90). Pre II. mikulčický kostol je dôležitá situácia hrobov č. 44 a 74 . Z hrobu č. 44, ktorý sa nachádza nad hrobom 74, pochádzajú bronzové ostrohy s tvárami a vel’ké gomíbky s palmetami (Poulík 1957, obr. 75). V hroboch staršieho horizontu na pohrebisku v Starom Městě Na Valách sú doložené šperky tzv. novej vlny, napr. 129/49, 282/49 alebo 299/49. Inventár všetkých troch spomínaných hrobov je zjavne analogický inventáru ženských hrobov č. 38 a 63 z Břeclavi-Pohanska pri hrobe č. 65 s mečom. Inventár hrobov z Pohanska tvoria náušnice s prelamovaným stĺpčekom, náušnice s klasovitým hrozienkom a drobné tepané gombíky s motívom palmety alebo vtáčika. Inventár hrobu č. 63 z Pohanska obsahuje aj náušnice typu Trilj, ktorý sa vytráca okolo polovice 9 . storočia (Chorvátová 2018a, 127, pozn. č. 15). Ak máme pre tzv. novú vlnu šperku, konkrétne pre jej neskoršiu obmenu prírodovedné datovanie, ktorá ju vymedzuje poslednou tretinou 9. storočia (Macháček - Dresler-Přchystalová - Sládek 2016, 169), tak potom aj na základe vyššie uvedených údajov nie je vylúčené, že na pohrebisku Na valách v Starom Městě a tiež na pohrebisku Břeclav-Pohansko pri kostole vzhl’adom na poznatky v súvislosti s typologickou analýzou meča a radiokarbónovým datovaním hrobu č. 65 sa začali šperky tzv. novej vlny do hrobov ukladat' pomerne skoro, a to v priebehu prvej polovice 9 . storočia.

Obmena v novej vlne šperku, čo je možné chápat' aj ako tretí horizont (Chorvátová 2015, 160-162), nastala pravdepodobne niekedy okolo polovice 9. storočia. Pri bližšom chronologickom určení tejto obmeny je možné vychádzat' aj z vertikálnej stratigrafie hrobu č. 44 pri druhom mikulčickom kostole (Poulik 1957, obr. 75). Honosný šperk sa vytráca zo ženských a detských hrobov pravdepodobne niekedy od konca 9. stor. a začiatkom nasledujúceho veku, ale definitívne v priebehu prvej polovice 10. storočia (Macháčék - Dresler - Př́chystalová 2019, 341).

Pôvod šperku novej vlny nie je doteraz uspokojivo vyriešený, ale niekol'ko indícií dovoluje uvažovat' o Franskej rišsi ako zdroji impulzov (Böbm 1941, 530). Faktom je, že presné tvarové analógie na území Franskej ríše nenachádzame. Istú podobnost' $\mathrm{k}$ stĺpčekovým náušniciam by sme mohli postrehnút' pri náušniciach, ktoré sú v nemeckej literatúre označené ako Bommelobrring mit sylindrischem Mittelteil (Stein 1967, 62, Taf. 89:14,15) alebo ako Obrringe mit Blecbbommel (Freeden 1979, 360-361). Uvedené náušnice zdanlivo pripomínajú jeden z typov stĺpčekových náušníc s plechovým stĺpčekom. Okrem tvaru majú nemecké i moravské náušnice spoločné ukončenie dolného oblúka náušnice, ktoré sa v našej literatúre uvádza ako esovitá kl’učka, na danú súvislost' už upozornil Š. Ungerman (2005, 712, pozn. č. 7). Vel’mi oblúbené boli v merovejskom i karolínskom období košíkové náušnice (Körbchenohrringe), ktoré však majú úplne odlišný tvar ako košíkové náušnice na Morave (Fingerlin 1974, Abb. 1:6). Spôsob zhotovenia košíkov na niektorých typoch je však vel'mi blízky technike Perldraht, ktorá sa objavuje na moravských koš́kových náušniciach a má dlhú tradíciu aj v predchádzajúcom merovejskom období (Eillbracht 1999, 77). Pozoruhodné je opät' rovnaké ukončenie dolného oblúku v tvare esovitej klučky ako pri stĺpčekových náušniciach. V prípade jedného páru devät'košíkovej náušnice z hrobu č. 317/49 zo Starého Města Na valách je obkolesená košíkmi i sklovitá vložka. V nemeckom národnom múzeu v Norimberku je uložená zlatá náušnica s troma košíkmi zhotovenými z filigránu, ktorá sa formou košíkov podobá na moravské košíkové náušnice.

Najnovšie Š. Ungerman zdroj inšpirácii k pôvodu honosného šperku opät’ hladá na území Byzantskej ríše, presnejšie z prostredia Balkánu (Ungerman 2018, tam i staršia literatúra). Najčastejšie sa predpokladá sformovanie vlastnej osobitej módy Moravanov (Ungerman 2005, 717; Galuška 2013, 253) pod vplyvom nových klenotníckych techník, sprostredkovaných prostredníctvom putujúcich klenotníkov. ${ }^{8}$

\section{Porovnanie intenzity zastúpenia hrobov s honosným šperkom v Čechách, na Morave a súčasnom Slovensku}

Nasledujúce výsledky (graf 1 a 2) nie sú z metodologického hladiska úplne najpresnejšie v tom zmysle, že pracujú s jednotlivými pohrebiskami ako so statickým celkom. Pritom je nepochybné, že pochovávanie na nich prebiehalo

\footnotetext{
7 Možnosti franských vplyvov sú širšie zdôvodnené v mojej dizertačnej práci (Chorvátová 2015, 168-174).

8 Š. Ugerman sa pokúsil objasnit’ proces tvorby honosného šperku Moravanov nasledovne: „Tito výrobci znalí náročných šperkařskéch technologii pake v našem

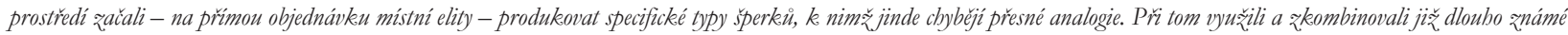

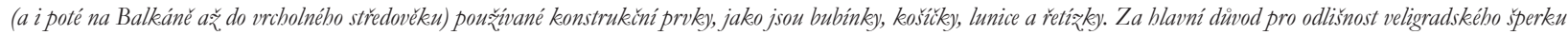
od typů známých odjinud pokládám fakt, že výrobci se museli rídit vkusem svých moravských odbèrateliu, keterý se poněkeud lišil od vkusu strédomořskébo." (Ungerman 2005, 717).
} 


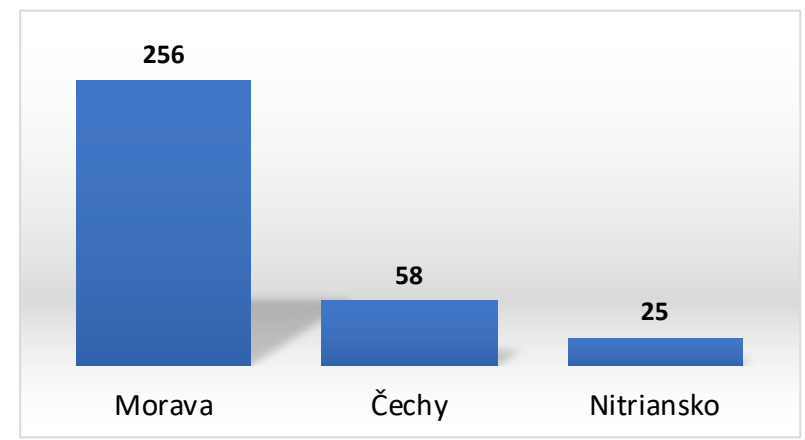

Graf 1. Počet hrobov s honosným šperkom.

Graph 1. Number of graves with luxurious jewelry (Moravia, Bohemia, Nitra).

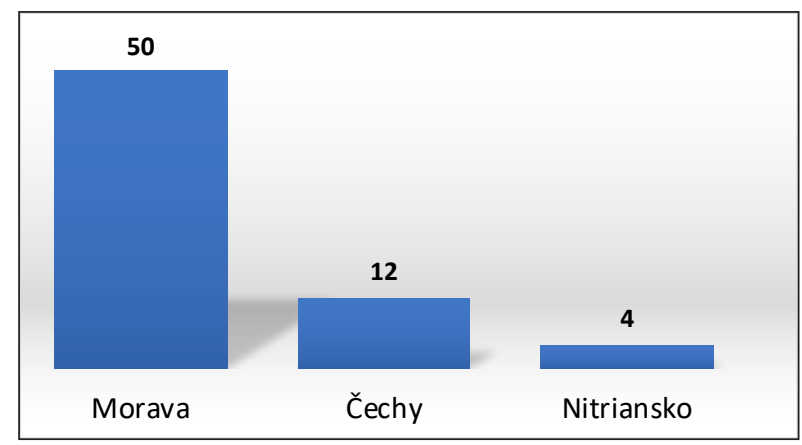

Graf 2. Počet extrémne bohatých hrobov s honosným šperkom - t. j. dva páry náušníc a pár gombíkov.

Graph 2. Number of extremly rich graves with luxurious jewelry - two pairs of earrings and a pair of buttons (Moravia, Bohemia, Nitra). niekol'ko desat'ročí, prípadne i viac než storočie. Počas celej doby existencie pohrebiska mohlo existovat' viacero fáz v pochovávaní, ktoré sa dajú odliśsit', ale dodnes chýbajú detailnejšie analýzy vnútornej chronológie pohrebísk, ako napr. pre Staré Město Na valách, Břeclav-Pohansko - prvý kostol alebo niektoré pohrebiská z Mikulčíc, najmä pri bazilike. Napriek uvedenému nedostatku je možné pre skúmaný jav - intenzita prítomnosti honosného šperku - pracovat' s doterajšími dostupnými výsledkami z výskumov pohrebísk, a zároveň sa opierat' o vyššie načrtnuté poznatky z relatívnej sekvencie honosného šperku, ako aj z typologickej rady tepaných gombíkov (Chorvátová 2008). Našt'astie pri niektorých lokalitách už aj dnes disponujeme presnejšími informáciami o ich datovaní, napr. pohrebiská pri 7. (Kouřil 2010, 63) a 12. kostole v Mikulčiciach (Profantová - Kavánová 2003, 336-338) a Břeclav-Pohansko - rotunda (Macháček - Dresler - Prichystalová - Sladek 2016, 140n).

Z grafov 1 a 2 nevyplýva niečo, čo by odbornej verejnosti nebolo známe. Najintenzívnejšie je honosný šperk zastúpený práve na južnej Morave. Čiastočným prekvapením však môže byt' porovnanie intenzity zastúpenia hrobov s honosným šperkom v stredných Čechách (58 hrobov) a na niekdajšom Nitriansku' (25 hrobov). Z územia Čiech poznáme niekol'ko väčších pohrebísk ako Stará Kourim (Šolle 1960) alebo pohrebisko na Pražskom hrade - Lumbeho zahrada (Frolik-Smetánka. 2014) a niekol'ko ojedinelých hrobov so zastúpením honosného šperku, a to aj extrémne bohatých, napr. Kolín (Košta - Lutovský 2014) alebo Želénky (Sklenár 1985). Ob-

last' juhozápadného Slovenska, teda predpokladané Nitriansko, výrazne zaostáva nielen v celkovom počte nálezísk s honosným šperkom, ale najmä v zistených hroboch s mimoriadne bohatými hrobmi, t. j. s dvoma pármi náušníc a párom gombíkov. Prekvapujúce je to najmä z dôvodu, že Nitriansko je od čias Mojmíra I. považované za dôležitú súčast' vel’komoravského „raného štátu“, a to od počiatkov vzniku tohto mocenského útvaru, ktorý historiografia tradične spája s rokom 833. Určitý mocenský a kultúrny vzostup tohto regiónu, ktorý malo obývat’ osobitné politicko-etnické spoločenstvo predpokladajú (najmä) slovenskí historici a archeológovia ešte za čias Pribinu a jeho bližšie neznámych predchodcov, teda zhruba pred rokom 833 a najneskôr po dezintegrácii Avarského kaganátu koncom 8. storočia (Bialeková 1980; Štefanovičová 1989, 82; 2005; Steinbübel 2016, 111-115).

Na území, ktoré sa v literatúre poníma ako Pribinovo Nitriansko, však obdobné nálezy bohatých ženských okrás - do výraznej miery indikujúce výraznejšiu mocenskú a sociálnu stratifikáciu ich nositeliek - podstatne absentujú. $\mathrm{V}$ porovnaní s českým územím, ktoré bolo tiež v bezprostrednom susedstve (a v istom momente aj v politickom spojenî) s mojmírovským kniežatstvom, je na východ od Váhu prítomnost' honosného šperku pomerne nižšia. Z juhozápadného Slovenska poznáme doposial' porovnatel'ne nižší počet aj rozsah pohrebísk z 9. storočia, ako v českom prostredí; napr. obdobne bohaté nekropoly ako Stará Kouřim alebo Lumbeho zahrada na Slovensku ne-

9 V slovenskej a českej historiografii sa ako Nitriansko označuje východná čast’ Vel'kej Moravy (v 9. storočí) a zároveň aj severozápadná čast’ Uhorska ako predpokladané údelné kniežatstvo Arpádovcov (v 10. - 11. storočí). Kniežatstvo s centrom v Nitre sa podl'a najčastejšieho výkladu rozprestieralo už od prvej tretiny 9. storočia približne na území dnešného západného a stredného Slovenska (podl’a Hudáčk. 2018, 33-34, pozn. 28). Avšak pre danú oblast' v prameňoch z 9. storočia (ale ani z 10. - 12. stor.) nepoznáme konkrétne kmeňové alebo etnicko-politické označenie (pozri Hudáče 2018, 33-34, pozn. 28), ako je tomu napr. pri Morave a Čechách, pri ktorých disponujeme názvom „kmeňa“ (gens Maravorum, Bohemani), či pri označení územia bývalej rímskej Panónie (provincia Pannonia). Meno „kmeňa Nitravanov“ nijaký dobový prameň explicitne neuvádza. Ku koncepcii starého Nitrianska pozri predovšetkým Steinhübel (2016, 111-115, 505-514 a passim). 
evidujeme. Pritom napr. šperk z mohylníka v Skalici (Budinský-Krička 1959) sa za súčasného stavu poznania javí ako isté pokračovanie podunajského šperku tak, ako ho ponímal J. Eisner (1947), a skôr ho môžeme spojit' so šperkom z najstaršieho horizontu - teda šperkom avarskej tradície. Zároveň by sme si mali pripomenút' polohu Skalice, ktorá je vzdialená od Starého Města cca $35 \mathrm{~km}$ a zrejme prináležala k moravským centrám. Podobne ani pohrebisko na Bratislavskom hrade, odkial sú známe nálezy honosných gombíkov a náušníc (Štefanovičová 1975, 122) nie je možné z mocensko-politického hladiska jednoznačne priradit' k regiónom Nitrianska (König 2017, 14). K lokalitám s honosným šperkom nemôžeme zaradit' ani pohrebisko Nitra-Lupka, napriek bohatosti niektorých hrobov. Na pohrebisku sa totiž objavuje typ šperku - tzv. šperk nitrianskeho typu (Chropovský 1962), ${ }^{10}$ ktorý má pravdepodobne iný pôvod a nedosahuje honosnost' šperku z južnej Moravy. Na území predpokladaného Pribinovho Nitrianska máme len štyri malé pohrebiska, ktoré prináležia pravdepodobne k mocenským centrám - Ducové (Hanuliak. 2004, tab.: XXXIV: 3-7), Nitra - Mikov dvor (Fusek 2008, 278-280), Bíňa (Holč́k 1991) a Mužla-Čenkov (Hanuliak - Kolena - Ku乏̌ma 2012). Je zaujímavé, že kolekcie s honosným šperkom z Ducového, Bíne i Mužly môžeme zaradit’ až k poslednému (najmladšiemu) horizontu honosného šperku (Chorvátová 2015, 160). Viacerí bádatelia sa zhodujú v absolútnom datovaní najmladších typov náušníc a gombíkov do poslednej tretiny 9. storočia (Profantová - Kavánová 2003, 336). Pohrebiská zo Slovenska, na ktorých boli nájdené ojedinelé nálezy honosného šperku, ako Šal’a (Hanuliak. 1992), Čakajovce (Rejbolcová 1995), Pobedim (Vendtova 1969), Borovce (Stäšškeová-Štukouská 1997, 197-206) a Trnovec nad Váhom (Toč̉̌ 1971) môžeme priradit’ skôr k vidieckym pohrebiskám ako napr. Nechvalín na Morave. Z lokality Spišské Tomášovce je zaznamenaný ojedinelý nález hrobu s honosným šperkom (Staššiková-Štukovská et al. 2006, 187-234). V predpokladanom Pribinovom i neskoršom Nitriansku zatial' neevidujeme detské hroby s honosným šperkom.

Popri hroboch s honosným šperkom je tiež vhodné stručne uviest' situáciu s hrobmi s ostrohami na území Slovenska. Aj pri nich je pozoruhodná situácia. Podla poznatkov, ktoré sú známe k roku 2004, poznáme len 67 hrobov s ostrohami ${ }^{11}$ (v 17 hroboch bola zistená len jedna ostroha (Hanuliak 2004, 150-152), pričom na lokalitách spájaných s Nitrianskom sa vyskytujú iba ojedinele detské hroby s ostrohami; len raz boli v hrobe staršieho diet'at’a (infans II) a štyrikrát boli uložené $\mathrm{v}$ hrobe nedospelého jedinca (juvenil). Celkový počet hrobov zo slovenského územia Vel'kej Moravy, ktorý bol publikovaný k roku 2004, predstavuje viac ako 4000 objektov (Hanuliak 2004, 27). ${ }^{12}$ Hrobov s ostrohami však na Morave poznáme podstatne vyššie množstvo. Len na najrozsiahlejšom pohrebisku v Starom Městě $\mathrm{Na}$ Valách ich bolo zistených 92 kusov (Hrubý 1955, 182). Z hl'adiska porovnania výskytu a rozšírenia niektorých prvkov materiálnej kultúry nie je bez zaujímavosti, že v oblasti, ktorá sa bežne stotožňuje s Nitrianskym kniežatstvom archeológovia evidujú menej početné doklady t’ažkých zbraní a opaskových kovaní (Štefanovičová 2005; Kourül 2016, 109; Robak 2017a, 156-157), ${ }^{13}$ ako aj neskorší vznik hradísk (hradov) ako mocenských centier elity (Šalkovský 2015, 86-89). Nálezy bojovníckej výzbroje sú hojne doložené z lokality Bojná-Valy, kde bolo nájdených minimálne 70 exemplárov ostrôh a d’alšie mnohopočetné súčasti výstroje, ale ich prevedenie je strednej až nižšej kvality (Robak 2019a; 2019b, 455). Dané zistenia naznačujú, že tieto nálezy netreba nutne spájat's predstavitel'mi najvyššej spoločenskej vrstvy. Všeobecne v okolí Bojnej výrazne absentujú doklady mocenskej elity, ktoré by sme mohli zaradit’ do prvej polovice 9. storočia. Nositelia opaskových kovaní a ostrôh z Bojnej boli skôr príslušníkmi ozbrojenej posádky či družiny, pritom ich pôsobenie je možné opatrne spájat' až s druhou polovicou 9. storočia (Robak 2017c, 2019b). Zároveň z lokality Bojná-Valy, ktorá je v literatúre popisovaná ako mocenské centrum, nedisponujeme až na dve výnimky predmetmi súvisiacimi so ženskou populáciou (Robak 2019a, 111). ${ }^{14}$ Pri hradisku Bojná-Valy je okrem iného zaujímavé, že dosial' nebolo archeologicky zistené blízke pohrebisko z 9. storočia. Zatial’ boli identifikované jedine

\footnotetext{
10 Pohlad na datovanie tzv. nitrianskeho šperku ponúkla T. Štefanovičová (1990) a najnovošie i P. Langó (2012). Obaja autori ho datujú do záverečnej tretiny 9. storočia Autorka textu sa však prikláňa k pôvodnému názoru o chronologickom vymedzení B. Chropovského do polovice 9 . storočia (Chropovský 1962, 216).

11 Niektoré pohrebiská s výskytom ostrôh nie sú doteraz publikované, ako napr. pohrebisko Borovce a nedávny nález z lokality Bratislava-Vajnory.

12 Na južnej Morave podl’a informácie P. Kouřila bolo do roku 2004 zistených 7500 hrobov (ústna informácia, citované podl’a Hanuliak 2004, 28). Vzhl’adom na nižšie predložené závery o územnom a mocenskom charaktere Nitrianska môže byt' v budúcnosti užitočné (v istom ohlade) rozlišovat' medzi pohrebiskami z území na západ a východ od Váhu.

13 Nedávno došlo i k prehodnoteniu datovania nálezov, napr. meč a ostrohy z hrobu č. 23 z pohrebiska v Závade pôvodne datovaných do prvej tretiny 9. storočia. Nové chronologické určenie posúva nálezy až do druhej polovice 9. storočia (Robak. 2018). Porov. aj Štefanovičová 2005, kde čast’ uvádzaných nálezov po zohladnení zistení Z. Robaka, ako aj po odmietnutí chronológie blatnicko-mikulčického horizontu zrejme patrí až do druhej polovice 9. storočia.

14 S danou skutočnost'ou môže súvisiet’ najnovšia interpretácia účelu tejto lokality, ktorá podl’a Z. Robaka (2019, 111) plnila skôr funkciu vojenskej posádky, než sídla elít.
} 
dva relatívne izolované mohylové hroby (Pieta 2015, 37), z ktorých jeden je datovaný na základe radiokarbónového datovania do druhej polovice 8. až 9. storočia a druhý do 9. storočia (Robak 2017c, 204). Z. Robak pritom predpokladá, že spomínané mohylové hroby patria zrejme k staršiemu ústrediu z 8. storočia na blízkom vrchu Žihl’avník. Po opustení tejto lokality bolo založené nové hradisko Bojná-Valy, a to asi najskôr v druhom štvrt'ročí 9. storočia alebo aj neskôr (Robak 2017c, 212).

Pred časom upozornil na osobitost' Nitrianska T. König (2017). Vo svojej štúdii konštatoval, že východne od Malých a Bielych Karpát síce evidujeme analogické prejavy pohrebných zvyklostí, ktoré zodpovedajú situácii známej z Pomoravia. Avšak König upozorňuje, že „aj bez presnej kvantifikácie sledovaných javov možno konštatovat’, že početnost', rozsah a charakter nálezísk s dokladmi pochovávania je na oboch územiach predsa len odlišny. Nitriansko sa pritom vyznačuje celkovo menšim počtom a rozsahom pohrebisk, absenciou kostolných cintorinov a menej početnými dokladmi hrobov s inventárom poukazujúcim na príslušnost’ k spoločensky najvy šsize postavenej triede obyvatel'stva." (König 2017, 23). Vel'mi podobne sa v krátkosti vyjadril i P. Kouřil, ktorý rovnako zdôrazňuje výraznú kvalitatívnu odlišnost’ pohrebísk z juhozápadného Slovenska v porovnaní s moravskými, ktoré obsahujú hroby s výnimočnou kvalitou šperkov a mužskej výstroje v porovnaní s tzv. vel'komoravskými pohrebiskami na juhozápadnom Slovensku a tiež pripomína skromné doklady krest'anstva na východ od rieky Váh (Kouřl 2016, 109, pozn. 31).

Ako už bolo naznačené vyššie, kolekcie náušníc a gombíkov, a najmä samotné gombíky, mohli byt' vnímané ako pravdepodobný statusový artefakt moravskej elity (Klanica 1970, 424; Chorvátová 2009, 16-17). Ak by sme pripustili, že bohaté kolekcie zlatých šperkov sa objavujú na južnej Morave už niekedy na prelome 8. a 9. storočia, potom by bolo možné predpokladat' zásadné zmeny v sociálnej štruktúre už v danom období.

Predstavitelia elity zvyčajne pocit'ovali potrebu zdôraznit' i vonkajšie symboly svojho výsadného postavenia. Na potrebu externej prezentácie spoločenského statusu upozornila napr. N. Profantová (2001, 327): „Elita totiž musi viru společnosti nárokovat a od společnosti získávat u₹náni své výlučnosti tím spísé, čm ménè je jeji postaveni stabilizováno, aby tak dosábla spoločneské akeceptace, svébo uróujiciho, či alespoň prominentního vlivu. “15 Kultúrni a sociálni antropológovia opísali štyri skupiny spoločností podl’a spôsobu získavania spoločenského postavenia. Prvé dve society (segmentárne), čiže lovci a zberači a rodové spoločnosti, získavajú spoločenský status počas života svojou vlastnou aktivitou - úspešný lov, vít'azstvo nad súperom a pod. Predpokladá sa, že dané spoločnosti môžu archeológovia identifikovat' najmä bohatou výbavou mužských hrobov, resp. hlavne hrobov dospelých. K d’alším indikátorom významného postavenia patrí aj úprava hrobovej jamy a miesto hrobu v rámci pohrebiska. Nasledujúce dve skupiny l’udských societ rozlišujú vedci ako náčelnícke a štátne (Renfrew - Bahn 2001, 174-176). V prípade oboch spoločností nie je už spoločenské postavenie výsledkom vlastnej osobnej aktivity, ale spoločenský status sa odvíja od dlhodobejšieho časového horizontu a je spojený s postavením celej rodiny. Ak sú súčast’ou pohrebísk aj bohaté ženské a najmä detské hroby, sú pomerne spol’ahlivým indikátorom dedičného spoločenského statusu a teda dedičnej elity (Krekovič 2005, 10; Klápště 2005, 24-28).

Porovnanie intenzity zastúpenia ženských a detských hrobov s honosným šperkom na Morave, Čechách a Nitriansku vzbudzuje viaceré otázky. Na území spájanom s Pribinovým Nitrianskom, ktoré podl’a historiografického výkladu malo existovat’ ako osobitný mocenský celok už počas prvých desat'ročí 9. storočia, chýba výrazné zastúpenie bohatých hrobov s honosnými šperkami, ktoré môžeme prisúdit' nobilite. Zároveň je pomerne nízko zastúpený počet hrobov s ostrohami, pričom výrazne absentujú detské hroby s honosným šperkom a ostrohami. Daný stav si všimol aj Z. Robak (2017a, 156-157), ktorý sa však domnieva, že absenciu artefaktov spájaných s elitou (aristokraciou) môže vysvetl'ovat' postavenie Nitrianska ako „sekundárneho centra“ Vel'kej Moravy (Robak 2019b, 455). Podl'a takéhoto vysvetlenia by potom mala moravská nobilita prakticky rezignovat' na východné územia, kde sa nemala záujem usídl'ovat' a teda aj nechávat' sa pochovávat'. Preto, ak na jednej strane pre prvú polovicu 9. storočia aj neskôr v Nitriansku neevidujeme dostatok hrobov príslušníkov vyššie postavených skupín symbolizujúcich svoj status prostredníctvom pochovávania s luxusnými predmetmi, tak na strane druhej by to malo svedčit' skôr o fyzickej neprítomnosti pôvodom moravskej elity na západnom a strednom Slovensku. ${ }^{16} \mathrm{~V}$ poslednej časti (5. Diskusia)

15 Porov. Kalhous 2018, 43.

16 Takýto predpoklad by mohol platit' hlavne vtedy, ak by sme pripustili, že nálezy honosných šperkov nutne museli patrit' iba l'ud’om pôvodne sídliacim na Morave (Porovnaj napr. Zalavár). Avšak názory o neprítomnosti bohatých moravských jednotlivcov v Nitriansku nezohl'adňujú inak logickú možnost' prenikania kultúrnych trendov a módy moravskej elity aj na územie, ktoré predsa býva tradične prirad’ované k jadru Vel'kej Moravy (od r. 833). Otázka by sa teda dala postavit' nasledovne: prečo chýbajú v Nitriansku (resp. na východ od Váhu) charakteristické moravské šperky, ked’ Nitra mala byt' počas celej existencie Vel’kej Moravy súčast’ou jej ,jadra“? Domnievame sa, že v tomto ohl’ade hrá stav bádania iba minimálnu rolu. 
sa naopak pokúsime ukázat', že Nitra podl’a písomných prameňov od 30. rokov 9. storočia v skutočnosti vôbec nemusela zastávat' pozíciu sekundárneho centra (vel'ko)moravského kniežatstva. Oblast' pod Zoborom a d'alej na východ totiž mohla byt' pričlenená k moravskej (Svätoplukovej) doméne až niekedy po polovici 9. storočia. Zároveň hroby s ostrohami a s honosným šperkom, ktoré boli zistené na území predpokladaného Nitrianska spadajú podl’a súčasných poznatkov práve až do priebehu druhej polovice 9. storočia, ženské hroby skôr až do záverečnej tretiny. Procesy transformácie spoločenských väzieb, zmeny sociálnej stratifikácie a formovania elity, ktoré boli azda podnecované aj kontaktmi s franským prostredím, mohli na území východne od Váhu dosahovat’ v prvých dvoch tretinách 9. storočia nižšiu úroveň ako na Morave a v Čechách.

Uvedené zistenia z posúdenia intenzity zastúpenia šperku v jednotlivých oblastiach, spolu s novými názormi na absolútne datovanie, môžu otvorit’ nové perspektívy historických interpretácii. Napríklad aj ohladne zaužívaného naratívu o vzniku mojmírovského „raného štátu“ spojením dvoch kmeňových kniežatstiev, výsledkom čoho mal byt” tzv. vel'komoravský dualizmus. V d'alšom texte sa pokúsime naznačit' niektoré možnosti historického výkladu, ktoré vzišli na podklade aktuálnych archeologických poznatkov najmä zo štúdia šperku.

\section{Interpretácia poznatkov}

Nálezové okolnosti bohatých ženských a detských hrobov s honosným šperkom z aglomerácie Starého Města najmä z pohrebiska „Na valách“ z južnej Moravy nevylučujú ich chronologické vymedzenie intervalom záveru 8. a prvej tretiny 9. storočia. Prítomnost’ bohatých hrobov dovol’uje predpokladat' výraznú stratifikáciu spoločnosti a teda aj komplexnejšie spoločenské vzt'ahy a väzby. Pravdepodobne v relatívne krátkom čase komunity v priestore Starého Města naštartovali a zmenili dynamiku spoločenských vzt’ahov. Podl’a foriem najstarších kolekcií šperku vychádzajúcich z tradícií avarského kultúrneho okruhu, je možné pripustit', že vzostup society v aglomerácii Starého Města sa začal ešte počas existencie Avarského kaganátu. Nie je však vylúčená aj možnost’ nárastu ekonomickej sily istej skupiny obyvatel’ov regiónu Starého Města až po rozpade Avarského kaganátu. Ak datovanie najstaršieho horizontu kolekcí ženských okrás do záveru 8. a prvých desat'ročí 9. storočia vychádza zo správnych predpokladov, patria práve extrémne bohaté hroby z pohrebísk v polohách Na valách, Špitálky a Uherské Hradiště - Sady k najstarším kostrovým hrobom. Je pozoruhodné, že v ostatných oblastiach ako je Dolné Rakúsko, západné Mad’arsko a juhozápadné Slovensko nie je známa žiadna lokalita s vysokým počtom hrobov s tak výrazne bohatým honosným šperkom. Aglomerácia Staré Město na prelome 8. a 9. storočia doslova žiari zlatými šperkami a známe polohy sú výnimočné aj v rámci samotnej južnej Moravy.

Na základe horizontálnej stratigrafie na pohrebisku v Starom Měste Na valách je možné d’alej predpokladat', že pomerne skoro v prvých desat'ročiach 9. storočia boli bohaté kolekcie šperku avarskej tradície vymenené za úplne nové typy náušníc a tzv. gombíkov - novou vlnou šperku. Pôvod nových ženských okrás nebol zatial’ uspokojivo vyriešený. Niekol'ko indícií nevylučuje, ako už bolo spomenuté, zdroje inšpirácie vo Franskej ríši. Kolekcie šperku novej vlny sa začínajú objavovat' aj na d'alších dôležitých mocenských centrách južnej Moravy ako Břeclav-Pohansko a Mikulčice. Na oboch lokalitách neboli doposial' zistené celé kolekcie náušníc najstaršieho horizontu, vždy len ojedinelé exempláre, čiže sa začalo na nich pochovávat’ pravdepodobne s istým časovým odstupom od lokalít v aglomerácii Starého Města. Mocenské centrá Mikulčice i Břeclav-Pohansko ležia viac ako 50 km južnejšie od Starého Města. Aj vzhl'adom na geografickú polohu Starého Města môžeme opatrne predpokladat', že lokality ako Mikulčice alebo Břeclav-Pohansko predstavovali nové ohniská vznikajúceho moravského kniežatstva v priestore, v ktorom donedávna dominoval politický vplyv Avarského kaganátu. Bohatost’ hrobov naznačuje vznik nových politických štruktúr. Etablujúce sa elity Moravského kniežatstva získali a začali kontrolovat’ širšie územie pravdepodobne na úkor dovtedajšej avarskej dominancie. Je možné, že atribúty spojené s politickým aj kultúrnym vplyvom Avarského kaganátu, čiže staršie formy náušníc (zdobené na hornom oblúku) stratili na prít’ažlivosti a sociálnom význame, prestali byt' prestížnou záležitost’ou, a preto boli vo vel’mi krátkom čase nahradené kolekciami šperkov, ktorých inšpiračné zdroje zrejme pochádzali z novej kultúrne určujúcej oblasti - pravdepodobne z Franskej ríše, podobne ako pre ostrohy, opaskové kovania (Robak 2013, 2019b), lýtkové remene (Ungerman 2019) meče (Beloševič 2007, 410-411) ${ }^{17}$ alebo uspo-

17 Novšie monografické spracovanie problematiky karolinskych mečov z Mikulčíc (Košta - Hošek 2014) sme nemali k dispozícií. 
riadania sídel elity (Macháček 2005). ${ }^{18}$

Za významné doklady premeny spoločenských vzt’ahov je možné považovat' aj detské hroby s ostrohami, ktoré sú zaznamenané práve na všetkých troch dôležitých lokalitách; v Břeclavi-Pohansku, prvý kostol (hroby č. 138, 163, $205,225,230,269,280)$ a na niektorých pohrebiskách v Mikulčiciach, pri II. (hrob č. 44) a VI. Kostole (hrob č. 51, 70) (Profantová - Kavánová 2003) i Staré Město Na valách (hrob č. 307/49). Uvedený fenomén spájajú českí bádatelia s formovaním elity, dokonca do istej miery už dedičnej (Klápště 2005, 25-34; Profantová 2005).

V detských hroboch sa objavujú najmä ostrohy typu IA podl’a V. Hrubého alebo typ 9 podla Z. Robaka (Robak. 2013, 34). Výnimkou je hrob č. 205 z Břeclavi-Pohanska, kde sa vyskytli ostrohy typu IB (Biskupija-Crkvina). Výskyt ostrôh IA naznačuje, že za jednu generáciu sa spoločenské vzt’ahy natol’ko stabilizovali, že prestížny status prechádzal aj na d’alšie pokolenie - na deti. Vznikla spoločenská vrstva, ktorá nadobudla výrazný ekonomický vplyv a pevnejšie mocenské postavenie, čo umožňovalo jej najvyšším reprezentantom prezentovat' svoj status už prostredníctvom svojich detí a tiež možnost'ou budovat' „vlastnícke kostoly“, napr. rotunda Břeclav-Pohansko (Macháče Dresler - Př́chystalová - Sladek 2010) alebo siedmy kostol v Mikulčiciach (Kouřl 2010, 67). ${ }^{19}$

Informácie, ktoré prinášajú relatívno-chronologické sekvencie honosného šperku nabádajú otvorit’ i otázku formovania a vzniku ranostredovekého gens Moravanov. Nepochybuje sa, že daný identitotvorný proces začal na južnej Morave. Predložené zistenia však umožňujú presnejšie konkretizovat’ miesto a čas, kde dochádzalo k najstarším procesom upevňovania sociálnej a politickej identity Moravanov. Poznatky archeologického bádania naznačujú, že práve oblast' Starého Města patrila k hlavnému formujúcemu sa centru novovznikajúceho politického spoločenstva Moravanov. Najvy̌šśi predstavitelia „kmeňa“ dokázali pomerne rýchlo, snád’ už v čase vojen Karola Vel'kého a jeho syna Pipina proti Avarom, vyhodnotit' turbulentnú situáciu a nanovo zadefinovat' politické postavenie nimi ovládanej domény. Moravania sa tak v krízových časoch asi začali odkláňat’ od Avarského kaganátu a naštartovali prehlbovanie mocenských vzt’ahov s karolínskymi elitami aj samotným panovníkom (prítomnost' na Frankfurtskom sneme 822) i upevňovanie kultúrnych väzieb s krest’anským Západom, čoho výsledkom môže byt' i nová vlna šperku.

Situácia v stredných Čechách v sledovanom období je rovnako zaujímavá a v niektorých smeroch aj podobná ako na južnej Morave. Počet hrobov s honosným šperkom však nedosahuje takú intenzitu. Prvé bohaté hroby s honosným šperkom zo Starej Kouřimi môžeme klást’ niekde do polovice 9. storočia, podobne i ojedinelé hroby z Kolína i Želének. Tiež rovnako ako na Morave, aj v Čechách sa asi už od polovice 9. storočia objavujú detské hroby s ostrohami na pohrebiskách z dôležitých centier - Stará Kouřim a Pražský Hrad - Za jízdarnou (Smetánka - Hrdlička - Blajerová 1974). Uvedené nálezy dovol’ujú uvažovat' o stratifikácii spoločnosti a formovaní dedičnej elity, kultúrne ovplyvňovanej franským prostredím, už od prvých desat'ročí 9. storočia, na čo už dlhšie upozorňujú viacerí bádatelia nielen v súvislosti jednotlivých artefaktov (Profantová 2001) ale i celých sídelných kontextov (Machácék 2005). Nakoniec, výrazné postavenie českých kmeňových elít a ich časté (nielen) bojové stretnutia s karolínskou mocou sú zachytené vo viacerých správach franských letopiscov z tohto obdobia (súhrnne Skutil 1990).

\section{Diskusia: Neskoršie formovanie „vel'komoravského Nitrianska“?}

V predošlej časti bol na základe súčasného stavu poznania predostretý súhrnný rozbor archeologických prameňov, ktorý zatial' ukazuje, že výroba a používanie honosných šperkov v rámci území Vel’kej Moravy vykazovali signifikantné regionálne odlišnosti. Východná čast' mojmírovského kniežatstva - v historickej aj archeologickej spisbe stotožňovaná s tzv. Nitrianskom - sa javí byt' v rámci 9. storočia oproti územiam vlastnej Moravy, ako aj v porovnaní s priestorom stredných Čiech, charakteristická podstatne nižšou koncentráciou bohatých ženských ozdôb a takmer úplnou absenciou bohatých detských hrobov. Majitel'ky prepychovo zdobených náušníc a gombíkov podla všetkého stáli z hladiska socioekonomického rozvrstvenia jednotlivých komunít na o niečo vyššom stupienku než bežné obyvatel’stvo. Nižšie postavené zástupkyne lokálnych spoločenstiev totiž nemali možnost’ a prostriedky ostentatívne

18 Podobný fenomén možno pozorovat’ pri opúšatní „,nomádskeho dizajnu“ opaskových garnitúr, ktoré boli po rozpade kaganátu u naddunajských Slovanov nahrádzané opaskovou módou karolínskeho typu, vid’ napr. Robak 2019b, 454.

19 K procesu zakladania vlastníckych kostolov príslušníkmi z radov elity v karolínskom Bavorsku porov. Wood 2007, 33-48 
symbolizovat' svoj status (aj) prostredníctvom honosného šperku. ${ }^{20}$ Mohlo by to snád’ znamenat', že obyvatelia území, kde podl’a dostupných archeologických poznatkov iba vel'mi zriedka ukladali do hrobov nebohé ženy a deti s honosným šperkom, nemali v oblube luxusné a navonok pôsobivé klenoty, prostredníctvom ktorých mohli zároveň symbolicky deklarovat’ svoje postavenie? Vyvijala sa možno v oblasti západného Slovenska odlišná klenotnícka tradícia, pod ktorú by sme mohli zahrnút' menej význačné, a teda nie natol’ko honosné klenotnícke výrobky? Tieto otázky si snád' zaslúžia pozornost' d’alšieho bádania, no na tomto mieste sa s pomocou písomných prameňov pokúsime ozrejmit' možnost', že „menej výrazný“ šperk na území Nitrianska zretel’ne indikuje menej výrazné mocenské elity (Třsštík 2001, 110-112, 131-135; porov. aj Illás 2017, 211). Na základe predloženého pozorovania priestorovej distribúcie honosného šperku na strednom Dunaji a pomocou aktuálnych relatívno-chronologických sekvencií je možné postavit' hypotézu, že bohaté klenotnícke predmety (indikujúce aj bohatšie elity) sa začali objavovat' na územiach predpokladaného Nitrianskeho kniežatstva o niečo neskôr ako na Morave a v Čechách.

Zrejme nebude d'aleko od pravdy predpoklad, že honosné šperky moravského typu sa v obmedzenom množstve rozširovali do d’alších oblastí aj v dôsledku šírenia mocenského vplyvu Moravanov. ${ }^{21}$ Ako už bolo viackrát zdôraznené vyššie, zdá sa, že odlišný stav materiálnej kultúry v sledovaných regiónoch nemusí korešpondovat’ s tradičnou predstavou Pribinovho a vel'komoravského Nitrianska. V tejto súvislosti určite platí všeobecný postreh Š. Unger-

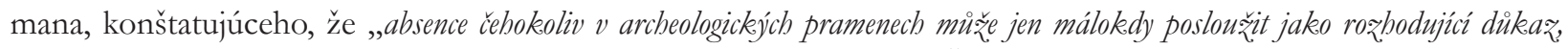
nebot' mư̌̌e být zprisobena mnoha rữnými faktory“ (Ungerman 2018, 520). Ďalšie indície však možno nájst' aj v zdanlivo „vyčerpanom“ textovom korpuse. Porovnanie archeologických zistení s obsahom niektorých písomných prameňov môže nasvedčovat', že kmeňová elita s význačnejším postavením, symbolizovaným navonok aj ženským a detským šperkom, bola na územiach východne od Bielych a Malých Karpát, prípadne - ako predpokladáme - na východ od Váhu, etablovaná až niekedy v druhej polovici 9. storočia. K tomuto chronologickému vymedzeniu nás vedie nielen stav archeologických prameňov, ale zároveň aj odlišné čítanie niektorých písomných zmienok. Podl’a slovenskej historiografie totiž Pribinove Nitriansko malo byt' samostatným mocenským útvarom, sformovaným po rozpade Avarského kaganátu už niekedy začiatkom 9. storočia, pričom asi po roku 833 sa malo stat' integrálnou súčast’ou „vel'komoravského štátu“ (Kučra 1974, 25; Marsina a kol. 1986, 88-92; Steinbübel 2002, 50-56; 2016, 111-126, 183 193; Lysý 2014, 83-107). ${ }^{22} \mathrm{Na}$ nasledujúcich riadkoch sa naopak pokúsime načrtnút' alternatívny výklad politického formovania tohto regiónu. Nové interpretovanie notoricky známych písomných prameňov môže signalizovat', že oblast' Nitrianska v prvej polovici 9. storočia ešte nebola zretel’nejšie politicky štruktúrovaná a zároveň ani nemusela tvorit’ súčast’ tzv. jadra Vel’kej Moravy. Na rozdiel od vžitej tézy o „vel’komoravskom dualizme“"23 a dobytí Pribinovho kniežatstva Mojmírom I., písomné pramene, domnievame sa, umožňujú spájat’ politickú integráciu území východne od Váhu do celku (vel'ko)moravského kniežatstva až s osobou Svätopluka. Takáto historická interpretácia môže zároveň vhodnejšie vysvetl'ovat' (ne)rozšírenie honosného šperku na územiach, ktoré mali tvorit' „Nitriansko.“

V prvom rade treba zdôraznit', že konvenčný historiografický výklad o vzniku Vel'kej Moravy okolo roku 833, ktorý sa mal udiat' zlúčením Moravského a Nitrianskeho kniežatstva ako dvoch autonómnych mocenských celkov a ktorý je opakovane reprodukovaný v odborných syntézach aj učebniciach, v skutočnosti nemá bezpečnú oporu

20 K sebaprezentácii socioekonomického postavenia prostredníctvom šperkov porov. Cooper-Al-Saad 2015, 82; Hayden 1998, 11-13. Šperk ako prostriedok demonštrácie blahobytu i určitej finančnej zábezpeky vo vrcholne a neskorostredovekej Byzancii analyzuje Parani 2019.

21 Skutočnost', že tieto osobité šperky vysokej remeselnej úrovne prenikali do okolitých krajín aj v dôsledku „územného rozširovania štátu“ konštatuje napr. Chropovský $(1995,24)$. V istom zmysle odlišnú situáciu možno pozorovat’ pri Zalavári/Blatnohrade, odkial’ poznáme väčšie množstvo honosného šperku analogického k vel'komoravským typom (Szökee 2010). Ženské šperky zo Zalaváru boli však väčšinou zhotovované z mede a bronzu, iba zriedkavejšie zo striebra (Szốke 2014, 267). Staršie bádanie zvyklo aj výskyt honosných šperkov zo Zalaváru odôvodňovat’ územnou expanziou Moravanov (porov. Trešstik 1991, 9-10). Rozšírenie klenotov tohto typu južne od Balatonského jazera sa však do istej miery dá spájat' práve s osobou vyhnaného Pribinu a jeho družiny. V prostredí Pribinovho a Kocel'ovho Panónskeho kniežatstva sa tak mohla etablovat' móda, ktorú si okruh Pribinovi blízkych ludí priniesol z naddunajských území (Ungerman 2018, 509). Avšak je podl’a nás otázne, či mohlo íst' o vplyvy práve z okolia Nitry, ked’že na rozdiel od bavorsko-moravského pohraničia v Nitriansku analógie k šperku zo Zalaváru príliš neevidujeme.

22 Stojí za zmienku, že zahraničné bádanie takýto interpretačný model nie vždy akceptuje (napr. Bláhová - Frolík - Profantová 1999, 195-199). Nedá sa ale povedat', že by svetová medievistika existenciu samostatného Pribinovho kniežatstva v prvej tretine 9. storočia zásadnejšie spochybňovala. Porov. Štih 1994, 209; Wolfram 1995, 312; Polek 2007, 290-305; Curta 2019, 117.

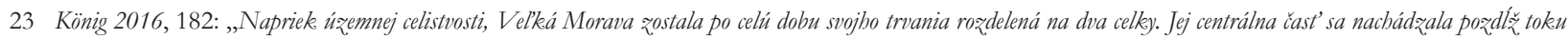
rieky Moravy, podl'a ktorej aj dostala meno. K tomuto územiu bolo užv obdobi jej zrodu pričlenené Nitriansko, ktoré však zostalo aj potom politicky spravované ako samostatné regnum.“ Takýto model „asymetrického vel'komoravského dualizmu“ (Steinbübel 2016, 159, 239; skôr napr. Ratkoš 1988, 36; Marsina 1993, 531) teda mocenského útvaru skladajúceho sa z pôvodne dvoch kmeňových kniežatstiev, pričom dobyté Nitriansko si malo udržat’ postavenie čiastočne autonómneho organizačno-správneho celku, kde mal údajne vládnut’ mladší príslušník mojmírovského rodu, ostáva dosial' bežne používaným (napr. Štefan 2011, 334), no zároveň asi príliš schematizujúcim vysvetlením vnútorného charakteru (vel’ko)moravského kniežatstva. 
v písomných dokumentoch (Bowlus 2009, 314) ani v archeologickom materiáli. ${ }^{24}$ Aj ked' predpokladanú Mojmírovu expanziu na juhozápadné Slovensko nezaznamenalo žiadne písomné svedectvo súdobých ani neskorších autorov, ${ }^{25}$ tak domáca ani zahraničná historiografia viac-menej nepripúšt'a iné vysvetlenie. Tradičná interpretácia je síce výsledkom logickej dedukcie, no priamo ju nepotvrdzuje nijaký prameň. Je totiž dobre známym faktom, že významnú konfrontáciu medzi moravským kniežat’om Mojmírom a „akýmsi“ Pribinom zachytil iba salzburský spis nazývaný Conversio Bagoariorum et Carantanorum. Prameň spísaný na popud bavorského arcibiskupstva (zhruba štyridsat' rokov po popisovanom Pribinovom vyhnaní) však na žiadnom mieste nespomína Mojmírovu expanziu ani dobytie Pribinovho kniežatstva, ale zaznamenáva iba informáciu o vypudení významného lokálneho vodcu do exilu (Sieklicki 1962, 1967; Harvát 2019, 44-50). Autor prameňa v tejto súvislosti (bez bližšieho záujmu) informuje, že Pribinu vyhnal knieža Moravanov Mojmír, pričom prvý menovaný - bez toho, že by bol spomenutý ako vládca osobitého kmeňa či územia - odišiel k východofranskému prefektovi Ratbodovi. ${ }^{26}$ Čítanie tejto pasáže v zmysle vojenského útoku na samostatné kniežatstvo a jeho knieža je až výsledkom invencie historikov, ${ }^{27}$ u niektorých slovenských autorov neraz aj voluntaristicky podmienenej. ${ }^{28}$ Najsilnejšiu indíciu o Pribinovom samostatnom kniežatstve väčšina bádania hladá práve v druhej mimovol'nej vete v Conversio, ktorá nepriamo (a poslednýkrát) referuje o pôvodnom území, odkial’ bol vyhnaný tento vysoko postavený vel’mož, či „,knieža bez kmeňa“. ${ }^{29}$ Dozvedáme sa z nej o vysvätení kostola „na mieste nazývanom Nitrava“ salzburským arcibiskupom Adalrámom ${ }^{30}(821$ - 836), avšak táto udalost' mala údajné prebehnút' iba na ,jeho majetku“ “. ${ }^{31}$ V skutočnosti potenciálne dôvody, ktoré mohli viest’ najvyššieho predstavitel’a bavorskej cirkevnej provincie k návšteve relatívne vzdialeného územia za Váhom nemáme potvrdené nijakým iným pramenným svedectvom - jediný údaj o Adalrámovej prítomnosti v Nitre pochádza výlučne z uvedenej vety Conversia. Napriek tomu sa najmä v slovenskej medievistike presadila nedostatočne podložená domnienka, že salzburský prímas mal putovat' do Nitry kvôli diplomatickej misii a získaniu si Pribinu na svoju stranu v boji proti Bulharom (Steinbübel 2016, 115-117). ${ }^{32}$ Ďalšie rozvažovanie možností a dôvodov výstavby enigmatického nitrianskeho kostola a (údajnej)

24 V súvislosti s vypovedacími možnost’ami archeológie sa to najvýraznejšie prejavuje aktuálnym odmietnutím chronológie tzv. blatnicko-mikulčického horizontu (Ungerman 2011, Robak 2017b). Hmotné nálezy, ktoré boli diskutabilne klasifikované pomocou tohto konceptu umožnili staršiemu bádaniu prirad'ovat' Pribinovmu kniežatstvu osobitú „,archeologickú náplň“. K tomu novšie Chorvátová 2018b. Skutočnost', že mojmírovská Morava sa stala teritoriálne „vel'kým“ politickým útvarom (ríšou) až za Svätopluka I. zvykne byt’ v bádaní akcentovaná. Napr. Havlík 1965, 110 , pozn. 4; Marsina 1992, 13.

25 Dôležitým argumentom, ktorý mal dokazovat’ Mojmírovú expanziu do Nitrianska (c. 833), sa aj pre historikov stalo dnes už archeológmi odmietnuté absolútne datovanie zániku hradísk na Slovensku (Pobedim, Majcichov, Bojná či Spišské Tomášovce) do 30. rokov 9. storočia. Napr. Ratkoš 1988, 33; Homza 2009, 128. Odlišne, no vychádzajúc z rovnakého datovania Tréstík 2001, 109. Aj ked’ Ján Steinhübel 2016, 190-191, pozn. 726 v druhom vydaní svojej monografie už zohl’adnil nové dendrodáta, ktoré zánikový horizont uvedených drevozemných opevnení určujú až do konca 9 . stor., resp. prvých desat'ročí 10. stor. (Henning-Ruttkay 2011), tak pôvodnú interpretáciu Mojmírovho útoku - založenú aj na prvotnom, ale nesprávnom datovaní - autor neaktualizoval. $\mathrm{Na}$ (do istej miery) násilné prispôsobovanie archeologických zistení interpretáciám vytvoreným na základe písomných prameňov poukazuje v tejto súvislosti Profantová 2003, 243-244.

26 Conversio 10, ed. Lošek 1997, 120: „In cuius spacio temporis quidam Priwina exulatus a Moimaro duce Maravorum supra Danubium venit ad Ratpodum.“

27 Znenie vety explicitne dezinterpretoval napr. Kučera 1985, 182, ked’ v protiklade k textu tvrdil, že autor Conversia zanechal „údaj o tom, že moravské knię̌a Mojmír vyhnal knieža Pribinu a jebo územie pripojil k svojej krajine [zvýraznil M.H.].“ Rovnako aj Ratkoš 1988, 51. V súčasnosti Ján Steinbübel 2016, 133-137 a passim interpretuje vetu z 10. kapitoly Conversia v zmysle Mojmírovho útoku na samostatné kniežatstvo, a to síce nad rámec textu prameňa, no podstatne dôslednejšie. Pri svojich záveroch sa navyše opiera aj o originálnu argumentáciu, ked’ predpokladá rozdielne „tri spôsoby vyhnania“, pričom ponúka aj jeden z možných výkladov d’alších nepriamych pramenných údajov (napr. tžv. Bavorský geograf či deperditný list Gloria in excelsis Deo zachovaný v Žitije Mefodija), ktoré podl’a autorovho názoru svedčia o Pribinovom kmeňovom kniežatstve „Nitrava“.

28 Stálo by za pokus vypracovat’ analýzu staršej aj súčasnej historiografie k otázke Nitrianskeho kniežatstva. Bolo by azda zaujímavé sledovat’, do akej miery československá historiografia aj archeológia od medzivojnového obdobia presadzovala výklad o spojení dvoch kniežatstiev predkov „,bratských národov“. Ďalej nakol'ko sa tzv. Nitriansko stalo objektom preukazovania ranestredovekej „existence Slovenska, jakožto zvláštní individuality geografické a historickê" (Chaloupecký 1923, 287), prípadne určitým prototypom zaniknutej slovenskej štátnosti pre l'udácku ideológiu (Hrušovský 1939, novšie napr. Ďurica 1995). Možno by sa tak podarilo z časti ozrejmit', akým spôsobom podmieňovala odborná snaha dokazovat’ existenciu ,priamych predkov Slovákov“ v ranom stredoveku (Kučera 1977; 1985; Marsina-Mulík 2009) samotné ćítanie a výklad písomných aj archeologických prameňov.

29 K postaveniu Pribinu novšie Štih 1994; Szőkee 2017. Vzhl’adom na (predpokladané) Pribinove Nitrianske kniežatstvo porov. aj Bláhová - Frolík - Profantová 1999, 196-197; Alimov 2015, 258-262.

30 Conversio 11, ed. Lošek. 1997: „Cui quondam Adalrammus archiepiscopus ultra Danubium in sua proprietate loco vocato Nitrava concescravit ecclesiam.“

31 Najnovšie David Kalhous (v tlači a osobná komunikácia) upozorňuje na skutočnost', že ak by autor Conversia považoval Pribinu za vládcu alebo správcu osobitnej oblasti, zrejme by nepoužil vágny výraz o ,jeho majetku“. Porov. aj skeptické postrehy V. Vavřínka (2013, 101-103). Martin Eggers 1995, 160 sa navyše domnieva, že nie je absolútne zrejmé, koho „majetok“ (Pribinov alebo Adalrámov?) mohol pisatel” mysliet’ pod „sua proprietas“. Nie príliš jednoznačnú formuláciu textu možno zohl'adnit’ pri bližšom ozrejmovaní dôvodov vloženia tejto vsuvky (pozri nižšie) do textu Conversia salzburským autorom.

32 Hypotézu skonštruoval Cibulka 1958, 252-257. K jej nepodloženosti kriticky už Třštík 2001, 115. Ešte častejšie sa predpokladá, že Adalrám prišiel do Nitry kvôli pravdepodobnej Pribinovej manželke z vilhelmovského rodu, ktorá mala priviest' so sebou z Bavorska aj krest’anský sprievod (prvýkrát zrejme už Rapant 1941, pozri najmä Wolfram 1995, 312; Steinbübel 2016, 121-124). 
Adalrámovej vysviacky, ${ }^{33}$ ktoré zamestnávali značný počet bádatel'ov počas celého 20. storočia, by bolo užitočné najmä v prípade, ak pripustíme hodnovernost' vety o Adalrámovej vysviacke z 11. kapitoly Conversia. Celá veta je však podl’a moderného bádania vsuvkou, vel'mi pravdepodobne až neskoršou (Lošek 1997, 123, pozn. 130; Wolfram 2012, 51). ${ }^{34}$ Preto čast' zahraničných bádatel’ov upozorňuje, že správu o Adalrámovej konsekrácii kostola vzhl'adom na postupy historickej kritiky nemožno považovat' za historický fakt (Bowlus 2009, 319, 327; Betti 2014, 153-154; Curta 2019, 116-117, pozn. 19). Ak predbežne nepripustíme hodnovernost’ Adalrámovho svätenia zachyteného iba v podozrivej a snád’ až v 10. - 12. storočí včlenenej vete, ${ }^{35}$ strácame tiež bezpečnú oporu pre konkrétnejšie lokalizovanie Pribinovej dŕžavy. Zmienka Conversia o vyhnaní z predošlej kapitoly totiž uvádza iba jeho príchod z územia „nad Dunajom“, čo eventuálne nevylučuje ani oblast’ na západ od Váhu. ${ }^{36}$ Detailnejšia diskusia k tejto problematike bude predmetom pripravovaného príspevku, naším ciel’om je na tomto mieste najmä zdôraznenie skutočnosti, že napriek postulovaniu dobytia Nitrianska Mojmírom ako historického faktu, o ktorom sa zvyčajne nepochybuje, tak práve naopak; tento nedostatočne preukázaný výklad treba problematizovat'. V nasledujúcom texte preto budeme pracovat' s možnost'ou, že obsah Conversia a mlčanie d'alších prameňov nepotvrdzujú dobytie predpokladaného Nitrianskeho kniežatstva v 30. rokoch 9. storočia.

Je však vel’mi zaujímavé, že v skutočnosti disponujeme písomnou správou informujúcou o moravskom ovládnutí územia, ktoré možno stotožnit' s čast'ou západného Slovenska. ${ }^{37}$ Ide o známy a nespočetnekrát interpretovaný Theotmarov list, čiže st’ažnost’ bavorského episkopátu, ktorá bola adresovaná pápežovi Jánovi IX (898 - 900). Spísanie tejto „petície“ podl'a najnovšieho diplomatického rozboru treba spájat’ s rokom $9000^{38}$ Čast' staršieho bádania sa síce vyslovovala za neautentický pôvod listu a jeho príslušnost’ k tzv. Pilgrimovým falzám z 10. storočia, no táto možnost’ sa už dlhšiu dobu odmieta (Marsina 1971, 82-88). Už česko-slovenskí historici, vydávajúci v roku 1969 český preklad listu (MMFH III, 232-244), a ešte o niekol'ko rokov skôr slovenský (Ratkoš 1964, 206-211), nepochybovali o jeho autenticite, ktorú presvedčivo potvrdilo moderné bádanie (Lošek 1997, 86-87; Tréstík 1998). Obsah st'ažnosti najvyšších predstavitel’ov bavorskej cirkevnej provincie voči Mojmírovi II. a jeho „pseudokrest’anským“ Moravanom väčšina bádatel’ov aj tak posudzovala z hl'adiska hodnovernosti textu iba vel’mi opatrne. Pohl’ad na Theotmarov list ako na príliš tendenčný a nie práve spol’ahlivý popis skutočností z konca 9. storočia sa prejavil aj pri interpretácii pasáže, ktorá uvádza dobytie a následnú konverziu „akéhosi novopokrsteného kmeňa“ Svätoplukom I. Autori písomnosti pripomínajú pápežovi, že práve k tomuto vojensky podmanenému „kmeňu“ (gentem) poslal jeho predchodca Ján VIII. na Svätoplukovo naliehanie Vichinga ako novovymenovaného biskupa. ${ }^{39} \mathrm{Z}$ dikcie a kontextu listu jasne vyplýva, že poslaním Vichinga (eum transmisit) ku kmeňu, ktorý si Svätopluk vojensky podmanil (bello domuit) mali autori na mysli zriadenie novej diecézy, pričom oblast', kde mal Viching ako nový biskup pôsobit' si bavorský episkopát podl’a listu - na rozdiel od Moravy - nenárokoval (Labuda 1988, 140-144; Tréstík 2001, 115-117, 123-125). ${ }^{40}$ Onen vojnou pričlenený a na vieru obrátený kmeň, či skôr územie ${ }^{41}$ hl’adali historici aj vo Vislansku (Widajewicz 1947, 71-74; Rat-

33 Napriek dlhoročným archeologickým výskumom a neúspešným snahám (B. Chropovský - Martinský vrch) lokalizovat’ kostol z 11. kapitoly Conversio, dodnes neboli jeho pozostatky v okolí Nitry bezpečne identifikované. K tomu Bednár 2006, 205n; 2012. Porov. aj najnovšie Bednár - Ruttkay 2018, 233-234. Netreba tiež zabúdat', že podl’a tvrdenia rovnakého prameňa bol Pribina pokrstený až po vyhnaní, čo samotnú existenciu kostola značne rozporuje. Tento rozpor v Conversio sa vysvetl'uje práve známymi hypotézami.

34 Naopak Treštík 2001, 113-114 a Lysý 2014, 87, 91 uvažovali o pôvodnej, ale pisatel’om iba nešikovne včlenenej vete, ktorá mala byt' údajne už súčast'ou rukopisného archetypu. Dušan Třestík. 2001, 114 však nezabudol dodat', že „Nic však k tomuto predpokladu prímo nenutí.“

35 Maddalena Betti 2014, 153 tvrdí, že veta mohla byt' včlenená do hlavného textu až po r. 880, teda až po vytvorení Vichingovho biskupstva. Možnost', že v skutočnosti ide o neskoršiu a najmä nehodnovernú interpoláciu sa pokúsim predostriet’ v pripravovanom príspevku (pozn. M.H.).

$36 \mathrm{~V}$ tomto ohl'ade treba nepochybne zohl'adnit' archeologickú situáciu Nitry a jej zázemia. Na základe hmotných prameňov síce býva Nitra 9 . - 10. storočia interpretovaná ako tzv. hradské mesto (Fusek. 2008; Ruttkay 2012), nálezový horizont datovaný do prvej polovice 9 . storočia je však až prekvapivo nevýrazný (upozorňuje na to Szóke 2017, 177). Často využívané tvrdenia o neskoršej kontinuálnej zástavbe Nitry dostatočne nevysvetl'ujú relatívnu chudobnost' nálezov z predvel'komoravského, ale aj staršieho vel'komoravského horizontu, čiže z čias údajnej prítomnosti Pribinu a jeho predpokladaného kniežacieho rodu v Nitre. Naposledy na túto skutočnost’ upozornil aj Vladimír Tuř́an (prednáška pre verejnost’ v Bratislave z dňa 28. 2. 2020 a osobná komunikácia). Nedostatok dokladov o elite z prvej polovice 9. storočia na území Nitry prízvukuje aj Z. Robak (emailová komunikácia).

37 Určitým svedectvom o podmanení si regiónu na západnom Slovensku Moravanmi v 9. storočí, môže byt' aj etymológia názvov niektorých obcí na tomto území (Moravany, Moravce). K tomu prehladne aj so staršou literatúrou König 2017, 19-23.

38 Obšírne aj s relevantnou literatúrou Lošek 1997, 55-87; podobne nové vydanie komentovanej edície Wolfram 2012, 230-231; pozri aj Třestík 1999, 717.

39 Epistola Theotmari episcopi, ed. Lošek 1997, 144: „Antecessor vester Zuentibaldo duce impetrante Wichingum consecravit episcopum, et nequaquam in illum antiquum Pataniensem episcopatum eum transmisit, sed in quandam neophitam gentem, quam ipse dux bello domuit et ex paganis christianos esse patravit."

40 Nemožno preto prijat’ názor, že malo íst’ o nejaké „misijné územie“, ako znenie listu pre(d)kladal Ratkoš 1988, 109. Porov. aj Marsina $1993,532$.

41 Klasifikovanie územia a jeho l'udí termínom gens v tomto prípade nemuselo nevyhnutne znamenat' vyprofilovanie osobitnej etnicko-politickej jednotky. Ako upozorňuje Denis Alimov 2015, 261 pisatel' listu mohol aplikovat' bežný termín, ktorý bol použivaný v rámci súdobého „etnického diskurzu“ 
koš 1988, 109) alebo v Potisí (Steinbübel 2016, 213-214). No pravdepodobnejšie treba prijat' lokalizáciu na území Slovenska v širšom okolí Nitry (Labuda 1988, 143-145; Třesttík 2001, 124-125; Lysý 2014, 97-101). Vzhl’adom na osobu Vichinga, ktorého vd’aka privilégiu Jána VIII. Industriae tuae z r. 880 vieme bezpečne spojit' s vytvorením biskupstva v Nitre (MMFH III, 205), musel bavorský episkopát písat' práve o Nitriansku. No aj bádatelia, ktorí síce na jednej strane pripustili, že v liste zostal zachytený údaj o podmanení si kmeňa v oblasti Nitry, na strane druhej jednoznačne odmietajú chronologickú hodnovernost' uvádzanej udalosti, ked’ tvrdia, že bavorskí biskupi v texte zamenili osoby moravských kniežat, pretože „Nitriansko predsa dobyl už Mojmir I.“ (Lysý 2014, 98, rovnako už Třešstike 2001, 116, 131; porov. aj Rapant 1974, 50-51, pozn. 12). ${ }^{42}$ Avšak takéto konštatovanie zostáva apriórnym postulovaním inak nedoloženej udalosti, ked’že podl'a našich vedomostí ani jeden prameň neobsahuje akúkol'vek zmienku o Mojmírovej(!) expanzii. Naopak, Theotmarov list, síce tendenčný, ale v tejto veci zrejme dobre informovaný43 hovorí pomerne jasne - Svätopluk si vojensky podmanil územie, kde bol práve ním ustanovený ako biskup Viching. ${ }^{44}$ Takáto interpretácia sa môže zdat' prekvapivá (obdobný výklad predmetnej pasáže už navrhol Bowlus 2009, 325-32755), no ak odmietneme možnost' pisatel’ovej kontaminácie s Mojmírom, potom sa dá pripustit', že text podáva autentické svedectvo. Vedia nás k tomu aj skutočnost', že dve vzájomné nezávislé historické tradície z vrcholného stredoveku spájajú násilné získanie regiónu v okolí Nitry práve so Svätoplukom.

V prvom rade ide o notorickú pasáž z Kroniky Cechov od Kosmasa († 1125). Pražský dekan, ktorý niekedy koncom 11. storočia navštívil Ostrihom, si zrejme na svojej ceste Uhorskom vypočul (pravdepodobne od Pudí žjúcich na juhozápadnom Slovensku) dlhodobo tradované Pudové rozprávania o Svätoplukovi (Kǚra 1977, 228-229; Steinbübel 2016, 262-263). Tieto dve odlišné povesti včlenil do svojho kronikárskeho diela. Kosmas pri rozprávaní o dávnom „král’ovi Moravy“ tak v prvej knihe okrem iného uvádza, že Svätopluk sa podujal na pokánie v Zoborskom kláštore, ked’že sa zachoval nespravodlivo voči cisárovi Arnulfovi, pretože ,podrobil si nielen Čechy, ale aj iné krajiny odtialto až k rieke Odre a odtial' smerom do Uhorska a ̃. ke rieke Hron. “46 Územie na dnešnom Slovensku si mal Svätopluk podl’a textu kroniky mocensky podmanit' (subiugarat), čím podl’a Kosmasa konal nespravodlivo a „nepamätajúc na dobrodenie“ cisára Arnulfa. Je zjavné, že postava Arnulfa tu v prvom rade slúži Kosmasovmu naratívu o obmedzeniach panovníckej moci, a teda aj širším zámerom jeho autorskej koncepcie dejín Čechov (Třestití 1968, 155-183; Wiboda 2019, 95). Pri tejto pasáži pražský dekan nepochybne vychádzal z Reginona z Prümu, ktorý začiatkom 10. storočia zaznamenal reálne Arnulfove postúpenie Čiech moravskému kniežat’u (Regin. chron. ad a. 890, ed. Kurže 1890, 134). Kosmas práve túto udalost' zjavne chápal ako spomenuté cisárove dobrodenie (beneficium). Čo však Regino nenapísal, a čo sa mohol Kosmas dozvediet' azda od obyvatel'ov Uhorska (Steinbübel 2016, 277), bola práve tradovaná alebo inak zistená informácia o Svätoplukovom zabratí území od Odry po Hron. V texte Kroniky Čechov tak zostala expressis verbis zachytená vzácna správa o tom, že územia siahajúce po rieku na strednom Slovensku pričlenil Svätopluk k svojej doméne.

Podobne ako pri Theotmarovom liste, ani Kosmasove tvrdenie väčšinu bádatel'ov nepresvedčilo a hodnovernost' informácie - tak ako je zaznamenaná v Kronike Čechov - historiografia odmieta. Zvyčajným vysvetlením je tvrdenie, že

pre označenie bližšie neznámeho územia a jeho obyvatel'stva.

42 Tvrdenie prameňa o Svätoplukovom dobytí Nitry býva hodnotené ako problematické. Herwig Wolfram považuje v svojom vydaní Theotmarovho listu uvedenie Svätopluka I. v predmetnej vete za dôsledok autorskej nevedomosti alebo kalkulácie („Unkenntnis oder Berechnung“) Wolfram $2012,236$. Obe možnosti nie sú príliš presvedčivé. Svätopluk bol predsa súčasníkom Theotmara a významným aktérom pôsobiacim v bezprostrednom okolí Bavorska. Ťažko preto hovorit’ o nevedomosti bavorského kléru. Vzhl'adom na údajné úmyselné zavádzanie prameňa nie je vôbec jasné, akým bavorským záujmom/nárokom by napomáhalo vykonštruované tvrdenie o Svätoplukovom dobytí Nitrianska. V tomto ohlade sú úvahy P. Baláža 2015 iba sotva pravdepodobné a autorom de facto fabulované nad rámec prameňov.

43 Viching pôsobil po odchode z Nitry (pred r. 891? k tomu Zavadil 2007) v Bavorsku a dokonca krátko pred spísaním prameňa aj ako formálne neuznaný biskup Pasova $(898$ - 899). Pasovský biskup Richard (Richarius) spomínaný v intitulácii Theotmarovho listu určite aspoň v hrubých obrysoch disponoval vedomost'ami o pôsobení svojho nelegitímneho predchodcu v jeho predošlej funkcii nitrianskeho biskupa. Nehovoriac už potom o salzburskom arcibiskupovi Theotmarovi, ktorý v roku 899 Vichinga osobne obvinil z protiprávneho držania biskupského stolca v Pasove (Lošek 1997, 57-58; Treśtík 2001, 120). Javí sa preto ako nepravdepodobné, aby si autori listu pri zmienke o vzniku novej Vichingovej diecézy na Svätoplukom dobytom území zamenili známeho súčasníka Svätopluka († 894) s dávno nežijúcim Mojmírom I.

44 Skutočnost', že Viching bol nominantom Svätopluka potvrdzuje bula Industriae tuae.

45 Hlavným ciel’om argumentácie Ch. Bowlusa je najmä neudržatel'ná lokalizácia Svätoplukovho panstva do juhovýchodnej Panónie. V súčasnosti už aj inak skeptickejší mimoeurópski bádatelia súhlasia (Curta 2019, 116), že názory I. Bobu, M. Eggersa a Ch. Bowlusa o alternatívnej polohe mojmírovskej Moravy neboli správne.

46 Cosmae Pragensis Chronica Boemorum I 14, ad a. 894, ed. B. Bretholz 1923, s. 32-33: ,Sed re vera tum in se ipsum reversus, cum recognovisset, quod contra dominum suum imperatorem et compatrem Arnolfum iniuste et quasi inmemor beneficii arma movisset, qui sibi non solum Boemiam, verum etiam alias regiones binc usque ad flumen Odram et inde versus Ungariam usque ad fluvium Gron subiugarat..." Preklad v MMFH I, 201 interpretuje text qui sibi [Svätopluk]...subiugarat v zmysle: ,,...Arnulf, keterý uvedl v jeho [Svätoplukove] područc‘. Takéto riešenie bolo použité zrejme aj preto, že staršie bádanie nepripúšt’a, že Svätopluk uvedené územia reálne dobil (pozri nižšie). Podl'a takého prekladu mal Arnulf vlastne moravskému panovníkovi územia od Odry po Hron, podobne ako Čechy, iba postúpit'. 
Kosmas prebral určenie východnej hranice Svätoplukovho novozískaného územia z neskorších udalostí. Rieka Hron by tak mala byt' spomenutá preto, že až sem zasiahlo t’aženie českého kniežat’a Břetislava I. z r. 1042 (komentár L. E. Havlíka v MMFH I, 201, pozn. 4; porov. Marsina 1971, 100). Takýto výklad však pôsobí násilné, ked’že Břetislavova výprava do Uhorska z roku 1042 (spoločne s král’om Henrichom III.) mala iba krátkodobý charakter, pričom nakoniec skončila neúspechom (Žemlička 1997, 64; Lysý 2004, 463). Břetislava preto nemožno spájat’ s reálnym teritoriálnym ziskom v Uhorsku. Nehovoriac o tom, že takáto možnost' následne pripúšt’a rozporné a protirečiace výklady u samotného Kosmasa, ktorý by tak zámerne alebo z nevedomosti(?) zamieňal Svätoplukove územné zisky s údajným přemyslovským podmanením si arpádovského Nitrianska. Pražský dekan totiž v svojej kronike t’aženie svojho oblúbenca Břetislava do (severného) Uhorska - ktoré v konečnom dôsledku nebolo úspešné - z pochopitel'ných dôvodov nespomína. ${ }^{47} \mathrm{Ak}$ by sme aj pripustili, že Břetislavovi I. (a Henrichovi III.) sa nakrátko podarilo mocensky podmanit' územia po rieku Hron (Ratkoš 1988, 56; Musil 2017, 265), ${ }^{48}$ aj tak je vel'mi nepravdepodobné, aby autor Kroniky Cechov - pre ktorého bol práve tento Přemyslovec „novým Achillom“ (Chronica Boemorum II 1, ed, Bretholz. 1923, 81) - na jednej strane explicitne nespomenul takéto skutočnosti, no na strane druhej o nich vedel, ale pripísal ich Svätoplukovi. Ešte nepravdepodobnejšia sa javí byt' možnost', že namiesto odrazu skutočnej situácie v 9. storočí, ide o Kosmasom (alebo jeho zdrojom) prenesené reálie zo storočia nasledujúceho, a teda z vôbec nie bezpečne preukázaného zabratia západného Slovenska kniežat'om Vratislavom I. alebo Boleslavom I. po r. 955 (Chaloupecký 1923, 37-38; Steinbübel 2016, 249, 309-311; k tomu kriticky Treštík 2000, 52, pozn. 41; Musil 2017, 263). ${ }^{49}$ Skutočnost', že predošlé bádanie hladalo pre Svätoplukov zábor území po rieku Hron iných panovníkov než toho, ktorého priamo uvádza samotný prameň, nepochybne vyplynula aj z častého presvedčenia (novšie König 2017, 11), že Kosmasov údaj v tomto prípade nemôže byt' správny, ked’že podl’a tradičného výkladu patrili územia na západnom Slovensku k moravskému kniežatstvu už od čias Mojmíra. ${ }^{50}$ Rovnaký problém možno pozorovat' aj pri doterajšom posudzovaní d’alšej vrcholnostredovekej kronikárskej tradície, ktorá umožňuje spájat' Svätopluka so ziskom území Nitrianska.

Druhým svedectvom z mladšieho obdobia, vzdialeným v čase vyše 300 rokov, je zmienka z Anonymovho diela Gesta Hungarorum. Kronika síce vznikla až okolo roku 1200, no preukázatel’ne (a neprekvapivo) čerpala zo starších písomných prameňov aj z ústne tradovaných príbehov (Kǔ́era 1977, 223-226; Steinbübel 2016, 269, 272-276; RadyVeszprémy 2010, xxvii-xxi). Jedným z takýchto l'udových rozprávaní, ktoré inšpirovali Anonyma, bola aj povest' o dobytí mesta Nitra útočiacimi oddielmi staromad’arského kniežat’a Arpáda. V súvislosti s rozprávaním o prvej konfrontácii medzi vojskami Arpádových vojvodov a obyvatel'mi Nitry podáva kronikár určitý obraz udalostí zo začiatku 10. storočia, $v$ istom momente však spomenie aj konkrétnu udalost’ z dávnejšieho obdobia. Na jednom mieste tak prameň uvádza, že vyslaní zvedovia ,spozorovali, že sa im obyvatelia onej krajiny, Slovania a Česi, stavajú s pomocon kniežat’a Cechov na odpor, pretože po smrti král'a Attilu knieža Čechov obsadil krajinu, ketorá leži medzi Váhom a Hronom od Dunaja až k rieke Morave, a spojil ju v jedno vojvodstvo, pričm v tej dobe sa z. milosti kniežat'a Čechov stal nitrianskym kniežatom Zobor. ${ }^{\text {"51 }}$ Anonymova kronikárska relácia je oproti Kosmovmu rozprávaniu nie len odlišná, ale na prvý pohl’ad aj nejednoznačnejšia, ked’že síce priamo nespomenie Svätopluka, ale iba vágne uvedie akési knieža Čechov (dux Boemorum). Pasáž je však o to zaujímavejšia, že predovšetkým popisuje územné a správne zjednotenie oblasti, ktorú chápeme ako Nitriansko. To sa malo podl’a Anonyma udiat’ až po obsadení krajiny - vymedzenej Váhom, Hronom

\footnotetext{
47 Výpravu inicioval senior Bŕetislava I. král Henrich III., ktorý zasa mal v záujme porazit’ uhorského krála Samuela Abu a dosadit' zosadeného a vyhnaného král'a Petra Orseola, čo sa spojeným ríško-českým vojskám podarilo až po bitke pri Menfő v roku 1044. Ešte v roku 1042, po relatívne skorom odchode česko-ríšskych vojsk z Nitrianska, Samuel Aba vyhnal nakrátko dosadeného arpádovca Domoslava (?) a usporiadal pomery severne od Dunaja opät' podl’a svojich predstáv.

48 O Henrichovom a Břetislavovom t’ažení, počas ktorého l’ahko zlomil odpor miest ležiacich až po Hron sa dozvedáme, na rozdiel od Kosmasa, zo správ ríšskych letopisov: Anales Althahenses maiores, MGH SS rer. Germ. IV, ed. Edmund L. B. von Oefele 1891, 31-32 a Chronicon Herimanni Augiensis ad a. 1042, MGH SS V, ed. Georgius H. Pertz 1849, 124.

49 Tu platí rovnaká výhrada ako pri dôvodení Břetislavom I.: prečo teda Kosmas o Vratislavovom alebo Boleslavovom podmanení Nitrianska nepíše, ale pri opise povesti o Svätoplukovi údajne práve pod vplyvom reálií z 10. storočia kontaminuje vlastný výklad, resp. obsah poveste, s ktorou sa stretol v Uhorsku?

50 Aj napriek kritickému hodnoteniu mnohých Kosmasových chronologických a faktických údajov, ktoré často nemusel preberat’ zo starších prameňov celkom správne (Treštík 1968,60-64) alebo ich dokonca úmyselne prispôsoboval autorskému zámeru (Sláma 2006), nevidíme relevantný dôvod prečo by táto konkrétna pasáž mala byt’ kontamináciou inak nesúvisiacich chronologických udalostí (Svätoplukove a Břetislavove (?) výboje).

51 Anonymi Bele regis notarii Gesta Hungarorum XXXV: De Nitria civitate, ed. a trans. M. Rady -L. Veszprémy 2010, 76: ,Qui cum velocissimo cursu venissent usque ad rivulum Turmas, ubi descendit in rivulum Nytre, viderunt habitatores illius provincie Sclavos et Boemos eis obsistere cum adiutorio ducis Boemorum. quia mortuo Athila rege terram, que iacet inter Wag et Gron a Danubio usque ad fluvium Morova, dux Boemorum sibi preoccupaverat et in unum ducatum fecerat et tunc tempore per gratiam ducis Boemorum dux Nitriensis factus erat Zubur."
} 
a Dunajom - oným kniežat'om Čechov. ${ }^{52}$ Koho mal autor na mysli, a čo možno z tejto pasáže vyvodit' o potenciálnom sformovaní vel'komoravského Nitrianska?

Postava nášho záhadného kniežat'a býva v literatúre už len podl’a názvu stotožňovaná prevažne s Břetislavom I. alebo iným Přemyslovcom (komentár L. Havlíka v MMFH I, 226; Musil 2004, 443)..$^{53}$ Vyššie sme zdôraznili, že Břetislavove vojenské akcie severne od Dunaja mohli byt’ iba t’ažko motiváciou k spájaniu jeho osoby s reálnym dobytím území siahajúcich po Hron. Z hl’adiska historickej doby, o ktorej referuje pasáž v Gesta Hungarorum, je omnoho pravdepodobnejšie uvažovat’ práve o 9. storočí. Vyplýva to už len z Anonymovej koncepcie starších dejín, pretože Attila je v jeho podaní jediným menovaným panovníkom (predkom Arpáda), po ktorom zrejme úmyselne neuvádza nijakých vládcov na strednom Dunaji a v Panónii, ked’že by narúšali jeho legendárnu genealógiu Arpádovcov. Jediných d’alších panovníkov či lokálnych vodcov, ktorých náš kronikár spomína, môžeme spájat’ až s 9. stor., resp. so začiatkom 10. stor., pričom ide práve o pololegendárneho Salana, Morouta, Menomorouta, ako aj o knieža Čechov, ktorých fiktívne postavy do výraznej miery autor odvodil z mocenských reálií mojmírovskej doby (Steinbübel 2016, 283-285, 323; Hudáček 2016, 12-19). Čo sa týka kniežat’a Čechov, ktorému Anonym pripisuje ovládnutie oblasti medzi Váhom, Hronom a Dunajom, ak neprijmeme nie úplne presvedčivú možnost’ o přemyslovskom vládcovi, tak väčšina indící ukazuje práve na Svätopluka.

Predovšetkým to vyplýva zo samotného textu, a to aj napriek tomu, že etnonymum „Moravania“ sa v kronike nevyskytuje. Z kontextu rozprávania je ale jasné, že „Čechmi“ mal Anonym na mysli práve Moravanov 9. storočia (Bartoňková 1965, 268-270; König 2016, 182). Autor kroniky totiž snažiac sa vykreslit' udalosti z čias staromad'arského „zaujatia vlasti“, hojne využíval toponymá - a do istej miery aj etnonymá - zo svojej súčasnosti (Musil 2004; RadyVeszprémy 2010, xxvii), preto aj pomenovanie Čechov (Boemi) očividne preniesol na dávnych Moravanov. Vyplýva to aj z porovnania podobných naratívov u mladšieho uhorského kronikára Šimona z Kézy, ktorý namiesto Čechov písal v podobných súvislostiach o „Mézanoch“ (Messiani), pričom v texte zjavne išlo o Moravanov (MMFH I, 264, 266; pozri aj komentár D. Kalhousa a Z. Měřínského v reedícii MMFH I 2019, 1177). Pri bližšom pohl'ade sa preto pomerne jasne potvrdzuje konštatovanie Dáše Bartoňkovej $(1965,268)$, že ako dux Boemorum „ovšem neni mínen nikedo jüný než. Svatopluk“. Aj napriek tomu, že Anonymove rozprávanie nemožno považovat’ za hodnoverný popis udalostí z 9. a 10. storočia (k tomu Ratkoš 1983; Musil 2004), jeho text prinajmenšom dokazuje, že ešte aj na konci 12. storočia pretrvávala „domáca“ tradícia (Kǔera 1977), ktorá spájala dobytie území na východ od Váhu s mocným kniežat’om Moravanov („Čechov“). Aj ked’ anonymný notár uhorského král’a Bela bližšie nešpecifikuje meno tohto kniežat’a, usudzujeme, že ide o ohlas reálnej historickej udalosti z čias Svätopluka I.

Hranice územia Nitrianska vymedzené Anonymom - ak ich nebudeme chápat' doslovne a v modernom zmysle slova, ale v súdobom kontexte (porov. Jaspert 2007) - predsa len nemusia mat' príliš d'aleko od reality 9. storočia. V tomto smere môže byt' zaujímavé chápanie hraníc kmeňového územia (starých) Moravanov, tak ako ich vyjadrila neskorostredoveká moravská tradícia. Moravský kompilátor Augustin zvaný Käsenbrot niekedy po r. 1499 zostavil katalóg olomouckých biskupov, kde okrem iného včlenil historizujúcu zmienku o pokrstení kmeňa dávneho moravského král'a Svätopluka. Stoji za pozornost’, že olomoucký a brniansky prepošt a kancelár napísal, že Svätoplukovi Moravania obývali územia medzi Vislou, Dunajom a Váhom(!) (Augustini Olomucensis Catalogus episcoporoum Olomucensium, 1511, A3). ${ }^{54}$ Bol to zrejme práve Augustin, kto ako jeden z prvých prepojil Moravanov 9. storočia s antickými Markomanmi (Wihoda 2010,16-17). O niečo neskôr spojil Markomanov s dejinami mojmírovskej Moravy aj Václav Hájek z Libočan (Kronika česká 11, ed. Flajšhans 1918, 50-51). Český kronikár síce takmer 30 rokov po Augustinovi pri opise hraníc dávnych Moravanov (bojujúcich s cisárom Augustom) výrazne popustil uzdu fantázii, ${ }^{55}$ ale rieku Váh ako určitý limit „království Moravského“ vôbec nekonkretizuje. Je preto celkom pravdepodobné, že kým popis hraníc u českého literáta prvej polovice 16. storočia treba považovat’ najmä za historickú fikciu, tak práve olomoucká tradícia spísaná o niečo skôr moravským kancelárom Augustinom zafixovala cez priepast’ storočí kolektívnu historickú pamät', ktorá mohla vychádzat’ zo skutočnosti, že Váh v karolínskej dobe tvoril určitú hranicu mojmírovskej

52 Ján Steinbübel 2016, 310-311 sa domnieva, že územie medzi týmito riekami tvorilo iba „malé Nitriansko“, čiže akési malé kniežatstvo fungujúce v 10. storočí v rámci maximalisticky chápaného (celého) Nitrianska.

53 Pozri aj komentár D. Kalhousa a Z. Měŕnského v novom vydaní MMFH I. 2019, 227, pozn. 1177.

54 „...(quae Vistula, Danubio ac Vago fluvio terminabatur)...“. Cit. podl'a viedenského vydania z r. 1511 (doplnená verzálka a čiarka pri slove vistula), dostupné na: https://daten.digitalesammlungen.de/ db/0000/bsb00003657/images/

55 Václav Hájek napr. písal o hraniciach Moravanov v Trácii a pri Jadranskom mori. 
moci (porovnaj obr. 2). ${ }^{56} \mathrm{~A}$ to až dovtedy, dokým sa ju moravský panovník so svojimi vernými vel’možmi nerozhodli posunút' d'alej na východ.

Slovenská historiografia predpokladá územný rozsah Nitrianskeho kniežatstva na základe maximalistického priestorového vyčlenenia oblasti, ktorú mal údajne ovládat' ústredný knieža z Pribinovho rodu, neskôr mladší Mojmírovec a následne v arpádovskom období ako „tretinu královstva“ aj údelný vojvoda z král’ovského rodu (Steinhübel 2010). Územie vel'komoravského Nitrianska tak podl'a slovenských bádatel’ov zaberalo takmer celé západné, stredné a aj značnú čast' východného Slovenska, ${ }^{57}$ avšak s výnimkou Bratislavskej brány, Záhoria, prípadne bez Žitného ostrova (novšie a opatrnejšie König 2017, 21-23, obr. 3). Takýto predpoklad by umožňoval uvažovat' o kniežati s nadregionálnou pôsobnost'ou a význačným mocenským postavením, ktoré si udržiaval už od začiatku 9. stor. a ktorý by tak mal aj na podmienky raného stredoveku ovládat' pomerne rozsiahle územie. Centralizovanejšia správa a socioekonomická súdržnost' tejto oblasti, eventuálne zjednotenej pod osobou ústredného vodcu (kniežat'a) s centrom pod Zoborom, však nie je doložená v nijakej súdobej písomnej zmienke, pričom dlhoročný archeologický výskum Nitry

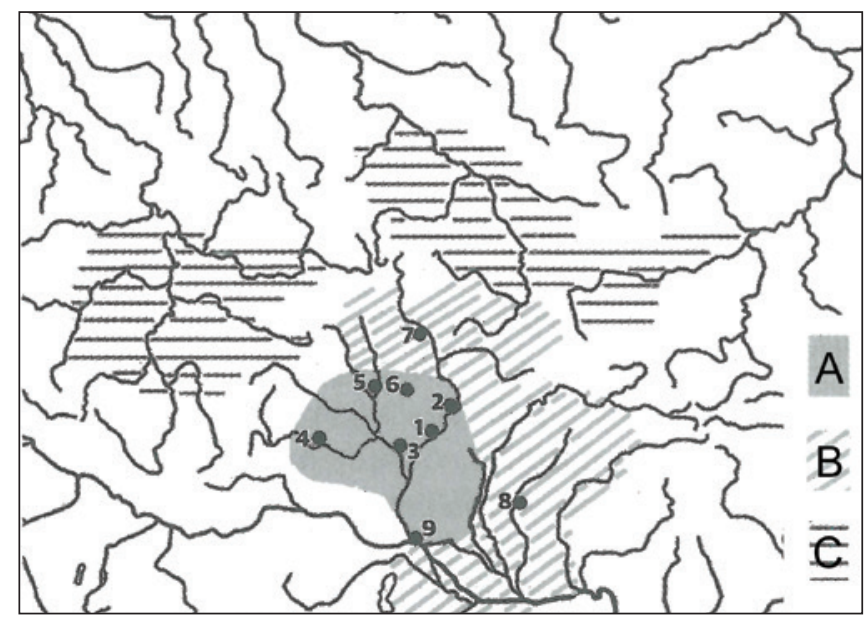

Obr. 2. Predpokladaný územný rozsah mojmírovskej Moravy okolo r. 890 (podl’a Wiboda - Macháček 2019, fig. 4.1, 96, upravené). Jadro moravskej domény na východe autori vymedzujú rámcovo riekou Váh. A - dedičná dŕžava, B - bezprostredne spravované oblasti, C - závislé územia pod mojmírovským vplyvom.

Fig. 2. The presumed territorial extent of Mojmír's Moravia around 890 A. D. (after Wihoda-Macháček. 2019, fig. 4.1, 96, modified). The authors delimited the eastern border line of Moravia by the river Váh. A - hereditary lands, B - directly controlled territories, $\mathrm{C}$ - dependent areas or territories under Mojmirids influence. tento predpoklad dostatočne nepotvrdzuje. Osoba „nitrianskeho kniežat’a“ tak zostáva skôr určitým historiografickým modelom, ktorý však rozhodne nemusí byt' jediným možným vysvetlením mocenskej organizácie týchto regiónov. Na základe (viacznačných) indícii v podobe dvoch pomenovaní Moravanov v texte tzv. Bavorského geografa (Marharii a Merehani: MMFH III, 287), alebo aj vd’aka údaju o akomsi na vieru obrátenom kmeni (neophitam gentem) z Theotmarovho listu, nie je vylúčené, že na území Slovenska už niekedy v 9. storočí skutočne jestvovalo osobité politicko-etnické spoločenstvo (novšie Lysý 2014, 106; König 2017, 9). ${ }^{58}$ Avšak, či k potenciálnemu „kmeňu“ odlišnému od Moravanov treba zarátat’ aj komunity žijúce na západ

56 V tejto súvislosti môže byt' pre budúce bádanie zaujímavé znova zhodnotit' aj opis hraníc pražskej diecézy v listine cisára Henricha IV. z roku 1086. Text sa zachoval v Kosmovej kronike a v odpise z 13./14. storočia (pozri Marsina 1971, 89-104; regest s textom opisu hraníc v CDS I, č. 60). Obsah písomnosti sa síce pol’a Kosmasa viaže k dobe sv. Vojtecha, no nie je vylúčené, že uvádzané vymedzenie pražskej diecézy vyjadrovalo zároveň nárok na územie Metodovho moravského biskupstva (Rapant 1974, 49-50, 52). V texte sa tak pri opise hraníc pražskej diecézy uvádza nielen ,provincia, ketorej meno je Váb“, ale taktiež sa rieka Váh spomína o niekol'ko riadkov nižšie ako východná hranica regione Moravia (Chronica Boemorum II 37, ed. Bretholz. 1923, 138). Za upozornenie na text listiny patrí naša vd'aka D. Kalhousovi.

57 Hranice vel'komoravského Nitrianska v rámci priestoru súčasného západného a stredného Slovenska vymedzujú napr. Marisna 1997, 7-8; Ruttkay 2012; Steinbübel 2016, 188-192, pričom ojedinelá nebola ani predstava, že Nitrianske kniežatstvo zasahovalo až na východné Slovensko (Ratkoš 1988, 56-58; Homza 2009, 127-128). Súhrnný prehl’ad názorov slovenského bádania na rozlohu Vel'kej Moravy a Nitrianska poskytuje Ivanič 2014. Pre slovenskú historiografiu zostáva osobitnou témou otázka územného rozsahu Nitrianska (chápaného ako „historické Slovensko“ alebo „Sclavinia“) v politickom rámci arpádovského Uhorska 10.-11. storočia. Maximalistický rozsah tzv. nitrianskeho údelného vojvodstva ako predpokladaného autonómneho arpádovského údelu, resp. tzv. tretiny král’ovstva sa v súčasnosti zakladá najmä na spornej interpretácií údajov o južnej hranici územných ziskov Boleslava I. Chrabrého z prvej tretiny 11. storočia a na arbitrárnom čítaní nie práve spolahlivej Uhorsko-pol'skej kroniky z 13. storočia (Homz̧a 1999; Steinbübel 2016, 386-387, 391-400). Mad’arské bádanie naopak oblast’ starého komitátu Nitra vníma ako jednu zo súčastí širšieho uhorského vojvodstva, teda nie ako samotnú „tretinu král'ovstva“, ale jej čast’ (porov. najnovšie Bagi 2017, 96-107 a passim).

58 Pri interpretácii etnoným z Bavorského geografa sa však nie vždy zohl'adňuje možnost', že jedno z pomenovaní Moravanov môže byt' až mladšou vsuvkou z neskoršej redakcie textu, snád’ po r. 882 (k tomu Ratkoš 1988, 55; Wiboda 2014, 46), čo by iba potvrdzovalo teritoriálny nárast mojmírovskej Moravy počas druhej polovice 9. storočia, ked’že autor pripísal druhým Moravanom takmer trojnásobný počet civitates. V prípade „,neophitam gens“ z Theotmarovho listu platí poznámka D. Alimova, že mohlo íst’ aj o etnickú interpretáciu autorov textu (pozri vyššie pozn. 41). V posledných rokoch nekritické bádanie, snažiace sa dokazovat’ existenciu osobitného kmeňa so „slovenským povedomím“ vedie k nepresvedčivému opakovaniu téz J. Stanislava a P. Ratkoša o kmeňovej osobitosti tzv. naddunajských Slovienov. Naposledy Baláž 2016; Homz̨a 2018. Tieto staronové názory svojvol’ne a bez akýchkol’vek pochybností prisudzujú rozličným komunitám sídliacim na území Slovenska, dokonca ešte pred 9. storočím, povedomie o „druhostupňovej“, nadkmeňovej slovanskej identite a zároveň aj povedomie o špecifickej regionálnej slovanskej/slov(i)enskej identite. Podl’a P. Baláža (2016, 7) by 
od Váhu ostáva otázne. Zatial' asi nemožno vylúčit', že východnejší región medzi Váhom, Hronom a Dunajom tvoril mocenský celok iba do obmedzenej miery. Navyše spoločenstvá na súčasnom strednom a východnom Slovensku, ktoré boli azda charakteristické nižšou mierou sociálnej diferenciácie a autarkným životným štýlom, mohli podliehat' skôr regionálnym vodcom a lokálnym centrám. Zároveň netreba zabúdat’, že mocenské pričlenenie široko vymedzeného územia popisovaného v literatúre (nie v prameňoch) ako Nitriansko k doméne Moravanov (už) počas prvých dvoch tretín 9. storočia nie je bezpečne dokázané.

\section{Záver}

Analýza hore uvedených pramenných zmienok a interpretácia archeologických zistení naznačujú, že sformovanie rozsiahlejšieho teritoriálneho celku s potenciálnym centrom v Nitre, ktoré Anonym omnoho neskôr nazval ducatus, sa udialo až v súvislosti s ozbrojenými aktivitami moravského Svätopluka. Nízka koncentrácia archeologických nálezov (nielen) honosného šperku na západnom a strednom Slovensku nedokladá (zatial’?) príliš bohatú elitu v prvej polovici 9. storočia a skôr dáva tušit', že vnútorná mocenská a spoločenská organizácia týchto regiónov nemusela byt' natol'ko komplexná a stratifikovaná, ako napr. na Morave. Počas 9. storočia niektoré prejavy materiálnej kultúry (ale aj sakrálna architektúra) pravdepodobne prenikali do východnejších oblastí stredného Podunajska iba postupne a s relatívnym oneskorením. Na územiach, ktoré sú tradične stotožňované s Pribinovým a následne „vel’komoravským“ Nitrianskom by sme teda mohli pripustit’ existenciu menej sociálne diferencovaných komunít s nižším stupňom politickej hierarchizácie, než v prípade aglomerácií a mocenských centier etablujúcich sa už v období okolo konca 8. storočia (Staré Město, Mikulčice, Brno-Staré Zámky, Bratislava a okolie?). Bohatou materiálnou kultúrou doložené formovanie mocenských elít je možné identifikovat' v Čechách a najmä na Morave, čiže v kontaktných zónach karolínskeho sveta. Populácie na juhozápadnom Slovensku, ktoré boli do prelomu 8. a 9. storočia o niečo pevnejšie zžité s Avarským kaganátom a jeho kultúrou, sa zrejme politicky a sociálne stratifikovali až relatvíne neskôr. 'Tým pádom by v budúcnosti bolo možné pokúsit' sa prehodnotit' doterajšie predstavy o jadre (Vel'kej) Moravy. Na rozdiel od predpokladania vel'korysého územného rozsahu Nitrianskeho kniežatstva by sa naopak dalo uvažovat' o regionálnom celku pri Bratislavskej bráne a v okolí Malých Karpát a d’al’šom mocenskom stredisku na Považí, pričom tieto mohli tvorit’ už od prvých decénií 9. storočia súčast’ moravskej domény. Samotné Nitriansko (kniežatstvo?) - siahajúce možno na východe niekde po Hron a na juhu po Dunaj - nemuselo byt' ešte v časoch Mojmíra I. a Pribinu (neistá spojitost's Nitrou) ani mocensky integrované do mojmírovského kniežatstva. Rieka Váh by potom nemusela byt' nutne vnímaná ako centrálna os vel'komoravského Nitrianska, ale skôr ako hranica kniežatstva Moravanov do vlády Svätopluka.

sa predpokladaný gens Nitrianska dal pomenovat’ ako „slovenskí Slovania“ (sic). Takýto metodologicky pochybný prístup k interpretácii písomných prameňov kriticky zhodnotil Lysý 2018, 41-42. 


\section{Príloha:}

\section{SÚPIS HROBOV}

Súpis obsahuje hroby so ženským honosným šperkom a s gombíkmi. Hroby s bohatými kolekciami, ktoré obsahujú minimálne dva páry náušníc a pár gombíkov, sú označené tučnými číslicami.

\section{MORAVA:}

STARÉ MĚSTO „NA VALÁCH“ (Hrubý 1955), hroby č.:

\section{ČECHY:}

12b/AZ, 13/AZ, 33/AZ, 69s/AZ, 83/AZ, 106/AZ, 121/AZ, 329/AZ, 5/48, 15/48, 22/48, 24/48, 25/48, 26/48, 33/48, 76/48, 108/49, 119/49, 129/49, 174/49, 205/49, 239/49, 251/49,252/49, 253/49, 281/49, 282/49, 284/49, 286/49, 290/49, 298/49, 299/49, 317/49, 323/49, $345 / 49,14 / 50,50 / 50,51 / 50,70 / 50,103 / 50,123 / 50,124 / 50,144 / 50$, 151/50, 162/50, 167/50, 178/50, 191/50, 2/51, 37/51, 40/51, 65/41, 83/51, 87/51, 95/51, 97/51, 105/51, 117/51, 122/51, 132/51, 145/51, 148/51,157/51, 167/51, 174/51, 189/51, 193/51,195/51, 196/51, 200/51, 202/51, 236/51, 252/51, 258/51. 277/51, 281/51

STARÉ MĚSTO „ŠPITÁLKY““ (Poulike 1955), hroby č.:

$1,2,13 \mathrm{~A}, 15,24$

UHERSKÉ HRADIŠTĚ „SADY“ (Galuška 1990), hroby č.:

19/59, 86/59, 103/59, 173/59, 209/59, 86/60, 87/60

BŘECLAV-POHANSKO, PRVÝ KOSTOL (Kalousek 1971), hroby č.: 9, 38, 43, 54, 63, 67, 70, 92, 84, 96, 97, 99, 127, 134, 135, 136, 141, 153, 158, 178, 197, 205, 225, 230, 256, 262, 270, 330, 336, 342, 344, 394

BŘECLAV-POHANSKO, ROTUNDA (Macbácée - Dresler - Prichysstalová

- Sládek 2010), hroby č.:

$52,82,103,120,132,136,143,171$

MIKULČICE, 2. KOSTOL (Poulik. 1957), hroby č.:

$1,4,44,50,51,64,65,67,69,71,76,85,95,97,98,100,102,104$

MIKULČICE, 3. KOSTOL (Klanica - Kavánová - Kouřl - Ungerman 2019), hroby č.:

$170,216,240,250,292,300,318,322,328,335,343,349,364,366,380$, $396,398,424,425,427,437,440,451,452,453,454,459,465,469,470$ 471, 472, 475, 473, 478, 488, 498, 504, 505, 508, 510, 512, 522, 525, 531, $540,549,550,553,557,567,569,580,588,589,592,625,659$ ?, 662, 675, $680,685,825,987,988,1181,1182$

MIKULČICE, 6. KOSTOL (Profantová - Kavánová 2003), hroby č.: 6, 42, 43, 51, 94, 118, 126, 152, 160, 178, 183, 190, 1479, 1481

MIKULČICE, 7. KOSTOL (Kouřl 2010), hrob č. 11

MIKULČICE, 12. KOSTOL (Profantová - Kavánová 2003), hroby č.: $1451,1459,1489,1506,1526$

NECHVALÍN (Klanica 2006), hroby č.:

44, 46B, 55, 103, 128, 130

RAJHRAD (Stan̆a 2006), hroby č.:

$70,165,166,186,461,466$

RAJHRADICE (Staña 2006), hroby č.:

KLECANY I (Profantová a kol. 2010), hroby č.:

2,53

KLECANY II (Profantová a kol. 2010), hroby č.:

6,28

KOLÍN, kniežací dvojhrob (Košta - Lutovský 2014)

LIBICE (Koštová 2014), hroby č.:

96c, 130, 134, 158, 159, 164, 245a, 268

PRAHA - LUMBEHO ZAHRADA (Frolik - Smetánka 2014), hroby č.: 16, 31, 53, 74B, 81, 82, 84, 89, 99, 100, 104, 108, 115, 116A

PRAHA - ZA JÍZDARNOU (Smetánka - Hrdlickea - Blajerová 1973 a za informáciu a možnost' ju zverejnit' d'akujem K. Tomkovej ), hroby č.: $1 / 47,15 / 51,42 / 51,11 / 83$

STARÁ KOUŘIM (Šolle 1960), hroby č.: 48, 49b, 86, 89, 95, 96b, 97, 106, 110, 112, 113a, 129, 136, 139

ŽALOV (Tomková a kol. 2012)

Výskum J. A. Jíry (1912 - 1913):

$11,22,31,52,53$

Výskum I. Borkovského (1949 - 1952):

$10,44,45,65$

Výskum 2003:

$11,14,17$

ŽELÉNKY (Sklenár 1985), ojedinelá mohyla s tromi pohrebmi, jeden z nich s nesmierne bohatou výbavou

\section{SLOVENSKO:}

BíŇA (Holčlk 1980; 1991), hroby č.:

detský hrob z roku 1978 a 14

BOROVCE (Stǎšsikeová-Štukovská 1990), hroby č.:

$26,35,49,145$

ČAKAJOVCE (Rejholcová 1995), hroby č.

$335,426,449,594,770$

DUCOVÉ (Hanuliak. 2004), hrob č.: 1070, 1210, 1460

MUŽLA (Hanuliak - Kolena - Kuгma 2012), hroby č.: $35,43 \mathrm{~A}$ 
NITRA - MIKOV DVOR (Fusek 2008), hroby č.:

$14,50,53$

POBEDIM II. (Vendtová 1969), hrob č.

48

SPIŠSKÉ TOMÁŠOVCE (Staššiková-Štukouská et al. 2006), jeden ojedinelý hrob
ŠAL’A (Hanuliak. 1992), hroby č.:

3,18

TRNOVEC NAD VÁHOM (Hanuliak. 1992), hroby č.: 330,357

\section{Zoznam použitých pramenných edícií}

Anales Althahenses maiores. In: von Oefele, E. L. B. (ed.): Monumenta germaniae historica, Scriptores rerum Germanicarum in usum scholarum separatim editi IV. Hannover 1891.

CDS I: Codex diplomaticus et epistolaris slovaciae I. Tom I. (Marsina, R., ed.). Bratislava 1971.

Cosmae Pragensis Chronica Boemorum. In: Bretholz, B. (ed.): Monumenta germaniae historica, Scriptores rerum Germanicarum Nova series. Berolini 1923.

Chronicon Herimanni Augiensis. In: V. G. H. Pertz (ed.): Moumenta germaniae historica, Scriptores (in folio). Hannover 1849.

Lošek, F. 1997: Die Conversio Bagoariorum et Carantanorum und der Brief des Erzbischofs Theotmar von Salzburg. Monumenta Germaniae Historica : Studien und Texte Band 15. Hannover.

MMFHI: Magnae Moraviae fontes historici. Tom. I. (D. Bartoňková et al., eds.), Brno 1967.

MMFH I 2019: Magnae Moraviae fonres historici. Tom. I (D. Bartoňková et al., eds.), [3. revidované a rozšírené vydanie]. Praha.

MMFH III: Magnae Moraviae fontes historici. Tom. III. (D. Bartoňková et al., eds.), Brno 1969.

Rady, M. - Veszprémy, L. 2010: Anonymi Bele regis notarii Gesta Hungarorum: Anonymus and Master Roger. Central European medieval texts, vol. 5. Budapest, New York.

Václav Hájek z. Libočan: Kronika českéa. Flajšhans, V. (ed.) 1918: I. Úvod. r. 644-904. Doba Pohanská. Praha.

\section{Pramene dostupné elektronicky}

Augustini Olomucensis Catalogus episcoporoum Olomucensiu. 1511, Viedeň. [Dostupné na stránkach Bayerische Staatsbibliotherk]: https://daten.digitalesammlungen.de/ db/bsb00003657/images/

\section{Bibliografia}

Alimov, D. E. 2015: В поисках «племени»: Посавское и Нитранское княжества в контексте этнополитической ситуации в славянском мире в IX в. [In search of a «tribe»: the Sava and Nitra principalities within the context of the ethno-political situation in the $9^{\text {th }}$-century Slavic world]. In: Исторический Формат 4, 246-273.

Bagi, D. 2017: Divisio regni : Országmegosztás, trónviszály és dinasztikus történetírás az Árpádok, Piastok és Přemys- 
lidák birodalmában a 11. és a korai 12. században. Pécs.

Balá̌̌ P. 2015: Pseudokrest'anskí Moravania, nitrianski neofyti a najkrest’anskejší Frankovia. Konštantínove listy 8, č. 1, 14-24.

Baláž, P. 2016: Dobové zmienky o existencii a pomenovaní slovanského kmeňa v Nitriansku. Historický zborník 26, č. $1,107-113$.

Bartoňková, D. 1965: Uherské prameny o Velké Moravě. Sborník prací filosofické fakulty Brněnské university F 10, 267-276.

Bednár, P. 2006: Nitriansky hrad v 9. storočí. In: Pieta, K. - Ruttkay, A. - Ruttkay, M. (eds.): Bojná. Hospodárske a politické centrum Nitrianskeho kniežatstva. Nitra, 205-216.

Bednár, P. 2012: Nitra v časoch pôsobenia sv. Konštantína-Cyrila a sv. Metoda. In: Panis, B. - Ruttkay, M. - Turčan, V. (eds.): Bratia, ktorí menili svet - Konštantín a Metod. Bratislava, 145-156.

Bednár, P. - Ruttkeay, M. 2018: Nitra and the Principality of Nitra after the Fall of Great Moravia. In: Kouruil, P. Procházka, R. (eds.): Moravian and Silesian strongholds of the tenth and the eleventh centuries in the context of Central Europe. Brno, 229-243.

Beloševič, J. 2007: Osvrt na karolinške mačeve tipa H sa šireg područja Dalmatinske Hrvatske: Rückschau auf karolingische Schwerter des Typus H aus dem Großraum des Dalmatinischen Kroatiens. Prilozi Instituta za Arheologiju u Zagrebu 24, 405-418.

Betti, M. 2014: The Making of Christian Moravia (858-882): Papal Power and Political Reality. Leiden, Boston.

Bialeková, D. 1977: Sporen von slawischen Fundplätzen in Pobedim (Typologie und Datierung). Slovenská archeológia 25, č. 1, 103-158.

Bialeková, D. 1980: Návrh chronológie praveku a včasnej doby dejinnej na Slovensku. Slovanské obdobie, Slovenská archeologia 28, č. 1, 211-221.

Böhm, J. 1941: Kronika objeveného věku. Praha.

Bowlus, Ch. 2009: Nitra : when did it become a part of the Moravian realm? Evidence in the Frankish sources. Early Medieval Europe 17 (3), 311-328.

Bláhová, M. - Frolike, J. - Profantová, N. 1999: Velké dějiny zemí Koruny české I: do roku 1197. Praha.

Budinský-Krička, V. 1959: Slovanské mohyly v Skalici. Bratislava.

Cibulka, J. 1958: Velkomoravsky kostel v Modré u Velehradu a začátky křest’anství na Moravě. Praha.

Cooper, H. K. - Al-Saad, Z. 2015: Metal Jewelry from Burials and Socioeconomic status in rural Jordan in Late Antiquity. Mediterranean Archaeology and Archaeometry 15 (2), 81-99.

Curta, F. 2019: Eastern Europe in the Middle Ages (500-1300). Leiden, Boston.

Cilinská, Z. 1966: Slawisch-awarisches Gräberfeld in Nové Zámky. Bratislava. 
Cilinská, Z. 1973: Frühmittelalterliches Gräberfeld in Želovce. Bratislava.

Čilinská, Z. 1975: Frauenschmuck aus dem 7.-8. Jahrhundert im Karpatenbecken. Slovenská archeológia 23, č. 1, 63-96.

Dostál, B. 1965: Das Vordringen der grossmährischen materiallen Kultur in die Nachbarländer. In: Magna Moravia. Praha, 361-417.

Dostál, B. 1966: Slovanská pohřebiště ze střední doby hradištní na Moravě. Praha.

Ďurica, M. S. 1995: Dejiny Slovenska a Slovákov. Martin.

Eilbracht, H. 1999: Filigran-und Granulationskunst im wikingischen Norden. Untersuchungen zum Transfer frühmittelalterlicher Gold-und Silberschmiedetechniken zwischen dem Kontinent und Nordeuropa. Köln-Bonn.

Eisner, J. 1947: K dějinám našeho hradištního šperku. Časopis národního musea CXVI, 142-162.

Fingerlin, G. 1974: Imitationsformen byzantinischer Körbchenohrringe nördlich der Alpen. Fundberichte aus Baden-Württemberg 1, 597-627.

Freeden, U. 1979: Untersuchungen zu merowingerzeitlichen Ohrringen bei den Alamannen. Bericht der römisch-germanischen Kommission 60, 231-441.

Frolike, J. - Smetánka, Z. 2014: Pohřebiště v Lumbeho zahradě na Pražském Hradě. Díl I. Katalog. Praha.

Fusek, G. 2008: Die Nebenareale in der Struktur der großmährischen Burgstadt von Nitra. In: Bohačová, I. - Polaček, L. (Hrsg.): Burg - Vorburg - Suburbium. Zur Problematik der Nebenareale frühmittelalterlicher Zentren Internationale Tagungen in Mikulčice VII. Brno 2008, 271-290.

Galuška, L. 1996: Uherské Hradiště-Sady. Křest’anské centrum říše velkomoravské. Brno.

Galuška, L. 2013: Hledání původu. Od avarských bronzů ke zlatu Velké Moravy. Brno.

Hanuliak, M. 1992: Gräberfelder der slawischen Population im 10. Jahrhundert im Gebiet der Westslowakei. Slovenská archeológia 40, 243-308.

Hanuliak, M. 2004: Vel’komoravské pohrebiská. Pochovávanie v 9.-10. storočí na území Slovenska. Nitra.

Hanuliak, M. - Kolena, B. - Kuzma, I. 2012: Základná antropologicko-archeologická charakteristika pohrebiska z prelomu 9. a 10. storočia v Mužle - Čenkova. Študijné zvesti AÚ SAV 52, 2012, 159-172.

Harvát, M. 2019: Úteky, vyhnanci a renegáti na moravsko-bavorskom pohraničí v 9. storočí. Forum Historiae 13 (2), $40-58$.

Hayden, B. 1998: Practical and prestige technologies: the evolution of material systems. Journal of Archaeological Method and Theory 5, 1-55.

Havlike, L. E. 1965: Politické osudy a zahraničné vztahy Velké Moravy. In: Ratkoš, P. (ed.): O počiatkoch Slovenských dejín. Bratislava, 104-140. 
Holč̉e, Š. 1980: Zist’ovací výskum v Bíni. Archeologické výskumy a nálezy na Slovensku v roku 1978. Nitra, 113-115.

Holč̉e, Š. 1991: Vel'komoravské pohrebisko v Bíni. Zborník slovenského národného múzea 85, Archeológia 1, 85104.

Homæa, M. 1999: Hranice nitrianskeho vojvodstva (kniežatstva) v pol'ských stredovekých kronikách. In: Marsina, R. (ed.): Nitra v slovenských dejinách. Martin, 63-78.

Homæa, M. 2009: Politické dejiny Spiša do začiatku 14. storočia. In: Homza, M. (ed.): Historia Scepusii. Vol. I. Dejiny Spiša I. Bratislava, Krakow, 126-311.

Hom₹a, M. 2017: Niekol'ko slov o identite Slovanov, včera, dnes i zajtra. In: Hurbanič, M. -Zervan, V. (zost.): Byzantinoslovaca VI. Byzantologický seminár Alexandra Avenaria pri Katedre všeobecných dejín FiF UK v Bratislave, Bratislava, 86-113.

Hruby, V. 1955: Staré Město. Velkomoravské pohřebiště „Na valách”. Praha.

Hrušovský, F. 1939: Slovenské dejiny. Turčiansky sv. Martin.

Hudáček, P. 2016: Castrum Salis : Severné pohraničie Uhorska okolo roku 1000. Bratislava.

Hudácée, P. 2018: Štefan I. a Boleslav Chrabrý. Obsadenie časti Uhorska podl’a Galla Anonyma a Uhorsko-pol'skej kroniky I. Historia Slavorum Occidentis 19 (4), 28-75.

Chaloupecký, V. 1923: Staré Slovensko. Bratislava.

Chorvátová, H. 2004: K relatívnej chronológii pohrebiska Staré Město v polohe „Na valách“, Acta historica neosoliensia 7, 199-235.

Chorvátová, H. 2007: Horizonty byzantsko-orientálneho šperku na tzv. vel'komoravských pohrebiskách, In: Turčan, V. zost.: Byzantská kultúra a Slovensko. Zborník Slovenského národného múzea Archeológia - Supplementum 2, Bratislava, 83-101.

Chorvátová, H. 2008: Gombíky s tepanou výzdobou. Zborník Slovenského národného múzea 102-Archeológia, 157174.

Chorvátová, H. 2009: Kultúrno-historický význam „gombíkov“. Studia Medievalia Bohemica 1, 7-19.

Chorvátová, H. 2015: Chronológia ženského honosného šperku vo včasnom stredoveku a jeho historický význam. Nepublikovaná dizertačná práca, Praha.

Chorvátová, H. 2018a: Schmuckkollektionen an der mittleren Donau. In: Nowotny, E. - Obenaus, M. - Uzunoglu-Obenaus, S. (Hrsg.): 50 Jahre Archäologie in Thunau am Kamp. Festschrift für Herwig Friesinger. Archäologische Forschungen in Niederösterreich, Neue Folge Band 5. Krems, 125-137.

Chorvátová, H. 2018b: Následný alebo paralelný vývoj avarských a tzv. vel'komoravských pohrebísk. In: Csütörtöky, J. (ed.): Iuxta Danubium, Spravodaj podunajského múzea v Komárne 16. Komárno, 144-150.

Chropouský, B. 1962: Slovanské pohrebisko v Nitre na Lupke. Slovenská archeológia 10, č. 1, 175-240. 
Chropovský, B. 1995: Prínos vel'komoravskej materiálnej a duchovnej kultúry do rámca európskej kultúry. Sborník prací Filozofické fakulty Brněnské univerzity/ Studia minora facultatis philosophicae Universitatis Brunensis E 40, 21-27.

Illášs, M. 2017: Niekol'ko úvah o Pribinovi, Mojmírovcoch a Vel’kej Morave (príspevok k diskusii o včasnostredovekých dejinách Moravy a západného Slovenska). Moravský historický sborník: ročenka Moravského národního kongresu. Brno, 179-247.

Ivanic, P. 2014: Problematika polohy a rozlohy Vel’kej Moravy v slovenskej historiografii. In: Vepřek, M. (ed.): Velká Morava a velkomoravská staroslovenština. Brno, 55-89.

Jaspert, N. 2007: Grenzen und Grenzräume im Mittelalter: Forschungen, Konzepte und Begriffe. In: Herbers, K. (ed.): Grenzräume und Grenzüberschreitungen im Vergleich- der Osten und der Westen des mittelalterlichen Lateineuropa. Akademie-Verlag. Berlin, 43-70.

Jurčević, A. 2011: Nalazi ranokarolinškog oružja i konjaničke opreme u doba formiranja Hrvatske Kneževine, Starohrvatska prosvjeta III. serlja - svazak 38, 111-147.

Kalhous, D. 2018: Úvahy nad možnostmi poznání sociální struktrury raně středověkého přemyslovského knížetství. Praehistorica 34/2, 29-82.

Kalhous, D. (v tlaci $)$ : Moravia Under the Mojmirid Dynasty in the $9^{\text {th }}$ Century : Political Power Units on the Peripheries of the Frankish Empire. Brno.

Kalousek, F. 1971: Břeclav-Pohansko. Velkomoravské pohřebiště u kostela. Brno.

Klápště, J. 2005: Proměna českých zemí ve středověku. Praha.

Klanica, Z. 1970: Velkomoravský gombík. Archeologické rozhledy 22, 421-445.

Klanica, Z. 2006: Nechvalín, Prušánky. Čtyři slovanská pohřebště. Díl I. Brno.

Klanica, Z. - Kavánová, B. - Kouřl, P. - Ungerman, Š. 2019: Mikulčice die Nekropole an der dreischiffigen Basilika. Studien zum Burgwall von Mikulčice XII. Brno.

Kleemann, J. 2010: Karolingisches Fundgut im Südosten und das Verhältnis lokaler Eliten zum Karolingerreich. Antaeus 31-32, 81-91.

Kolníková, E. 1967: Obolus mŕtvych vo včasnostredovekých hroboch na Slovensku. Slovenská archeológia 15-1, 189-254.

König, T. 2016: Nitrianski Slovania a zánik Vel’kej Moravy. In: Chudzińska, B. - Wojenka, M. - Wołiszyn, M. (eds): Od Bachórza do Światowida ze Zbrucza. Tworzenie się słowiańskiej Europy w ujęciu źródłoznawczym. Księga jubileuszowa Profesora Michała Parczewskiego. Kraków - Rzeszów, 181-191.

König, T. 2017: The Great Moravian territory of Nitra. Cultural manifestations, territorial scope and the ethnic and social-political identity of its population. Muzeológia a kultúrne dedičstvo 5, 2/2017, 9-28.

Košta, J. - Hošek, J. 2014: Early Medieval Swords from Mikulčice : Studien zum Burgwall von Mikulčice X. Brno. 
Košta, J. - Lutouský, M. 2014: Raně středověký knížecí hrob z Kolína. Fontes Archaeologici Pragenses, volumen 41. Praha.

Koštová, N. 2014: Pohřebiště na akropoli libického hradiště. Nové zhodnocení archeologického výzkumu. Neupblikovaná diplomová práca. Praha.

Kourĭl, P. 2010: Kirche Nr. 7. in Mikulčice. In: Poláček, L. - Maříková-Kubková, J. (Hrsg.): Frühmittelalterliche Kirchen als archäologische und historische Quelle Internationale Tagungen in Mikulčice VIII, Brno 2010, 57-69.

Kouřil, P. 2016: Staří Mad’aři a jejich podíl na kolapsu a pádu Velké Moravy aneb Spojenci, sousedé, nepřátelé. In: Macháček, J. - Wihoda, M. (eds.): Pád Velké Moravy aneb Kdo byl pohřben v hrobu 153 na Pohansku u Břeclavi. Praha, 102-143.

Krekovič, E. 2005: Pohrebisková archeológia. Študijné zvesti AU SAV 37, 2005, 9-12.

Kứera, M. 1974: Slovensko po páde Vel’kej Moravy. Bratislava.

Kứera, M. 1977: O historickom vedomí Slovákov v stredoveku. Historický časopis 25-2, 217-238.

Kučera, M. 1985: Vel'ká Morava a začiatky našich národných dejín. Historický časopis 33-2, 163-199.

Labuda, G. 1988: Studia nad początkami państwa polskiego II, Poznań.

Langó, P. 2012: Délszlávok Nyitrán? Megjegyzések az alsó ivükön tekercselt drótdíszes karikaékszerek (Southern Slavs in Nitra? Comments to the Classification of Earrings with Lower Arch Ornaments with Roundworend wire). In: Kozepkortorteneti tanulmanyok 7, A VII. Medievisztikai PhD konferencia, Szeged, 2011. junius 1-3. Szeged, 237-280.

Lysý, M. 2004: Politika českého kniežat’a Břetislava I. (1035-1055) voči Uhorsku. Historický časopis 52-3, 451-468.

Lysý, M. 2014: Moravania, Mojmírovci a Franská ríša. Štúdie k etnogenéze, politickým inštitúciám a ústavnému zriadeniu na území Slovenska vo včasnom stredoveku. Bratislava.

Lysý M. 2018: Slovania arcibiskupa Metoda na Morave a v Panónii. Konštantínove listy, roč. 11, č. 1, 40-50.

Macháček, J. 2005: Raně středověké Pohansko u Břeclavi: munitio, palatium, nebo emporium moravských panovníků? Archeologické rozhledy 57, 2005, 100-138.

Machácék, J. - Dresler, P. - Př́chystalová, R. - Sládek, V. 2016: Břeclav-Pohansko VII. Kostelní pohřebiště na Severovýchodným předhradí.

Macháčeke, J. - Dresler, P. - Př́chystalová, R. 2019: Das Ende Großmährens - Überlegungen zur relativen und absoluten Chronologie des ostmitteleuropäischen Frühmittelalters. Praehistorische Zeitschrift 93-2, 307-348.

Machácek, J. - Wiboda, M. (eds.) 2019: The Fall of Great Moravia. Who Was Buried in Grave H153 at Pohansko near Břeclav. Leiden, Boston.

Marsina, R. 1971: Štúdie k slovenskému diplomatáru I. Historické štúdie 16, Bratislava, 5-108.

Marsina, R. a kol. 1986: Dejiny Slovenska I (do roku 1526). Bratislava. 
Marsina, R. 1992: Poloha a rozloha Vel'kej Moravy. Slavica slovaca 7-1, 4-14.

Marsina, R. 1993: Nitrianske biskupstvo a jeho biskupi od 9. do polovice 13. storočia. Historický časopis 41 (5-6), 529-542.

Marsina, R. - Mulike, P. 2009: Etnogenéza Slovákov: Kto sme a aké je naše meno. Martin.

Musil, F. 2004: Gesta Hungarorum a historicko-zemepisný obraz Slovenska. Historický časopis 52-3, 433-449.

Musil, F. 2017: Recenzia: Ján Steinhübel, Kapitoly z najstarších českých dejín 531-1004, Krakov: Spolok Slovákov v Pol'sku, 2011. Mediaevalia Historica Bohemica, 20, č. 1, 259-268.

Parani, M. 2019: Byzantine Jewellery: The Evidence from Byzantine Legal Documents. In: Entwistle, Ch. - Adams, N. (eds.): „Intelligible Beauty“: Recent Reserch on Byzantine Jewellery (British Museum Research Publikation 178), London, 186-192.

Pavlovičová, E. 1996: K vypovedacej schopnosti gombíka u naddunajských Slovanov v 9. storočí. Slovenská archeológia 44, 95-153.

Petrinec, M. 2019: O nakitu iz Golubića i ženskoj nošnji iz razdoblja 8. i prve polovine 9. stoljeća. Starohrvatska prosvjeta III. serija - svezak/vol. 46.

Pobl, W. 2010: Archaeology of identity: introduction. In: Pohl, W. - Mehofer, M. (Hrsg.): Archaeology of Identity Archäologie der Identität. Forschungen zur Geschichte des Mittelalters. Band 17. Wien, 9-23.

Polek, K. 2007: Frankowie a ziemie nad środkowym Dunajem Przemiany polityczne i etniczne w okresie merowińskim i wczesnokarolińskim (do początku IX w.). Krakov.

Poulike, J. 1955: Nález kostela z doby říše velkomoravské v trati Špitálky ve Starém Městě. Památky archeologické 46, 307-351.

Poulike, J. 1957: Výsledky výzkumu na velkomoravském hradišti „Valy“ u Mikulčic. Památky archeologické 48, 241388.

Profantová, N. 2001: K průniku prvků franského životního stylu do Čech v 9. století (na základe poznatku archeologie). In: Galuška, L. - Kouřil, P. - Měřnský, Z. (eds.): Velká Morava mezi Východem a Západem. Brno, 327-338.

Profantová, N. 2005: Elita v zrcadle dětských pohřbů 9. a 10. století v Čechách. Študijné zvesti AU SAV 37, 63-80.

Profantová, N. - Kavánová, B. 2003: Mikulčice. Pohřebiště u 6. a 12. kostela. Brno.

Profantová, N. - Profant, M. 2003: Archeologie a historie aneb „jak vykopávati dějiny? In: Klápště, J. et al. (eds).: Dějiny ve věku nejistot. Sborník k př́ležitosti 70. narozenin Dušana Třeštíka. Praha, 239-250.

Profantová, N. a kol. 2010: Klecany. Raně středověká pohřebiště. 2. svazek. Praha.

Rapant, D 1941: Pribynov kostolik v Nitre. Elán, č. 3-4, 18-21.

Rapant, D. 1974: Drobné štúdie k slovenskému stredoveku. Slovenská archivistika 9-1, 47-79. 
Ratkoš, P. 1964: Pramene k dejinám Vel'kej Moravy. Bratislava.

Ratkoš, P. 1983: Anonymove Gesta Hungarorum a ich pramenná hodnota. Historický časopis 31-6, 825-870.

Ratkoš, P. 1988: Slovensko v dobe vel'komoravskej. Košice.

Rejholcová, M. 1995: Pohrebisko v Čakajovciach (9. - 12. storočie). Nitra.

Renfrem, C. - Babn, P. 2001: Archaeology. Theories Methods and Practice. Third edition. London.

Robak, Z. 2013: Studia nad okuciami rzemieni w typie karolińskim VIII-X wiek, I część. Nitra 2013.

Robak, Z. 2017a: Carolingian Decoration from Dolné Orešany. In: Fusek, G. (ed.): Archäologische Studien zum frühen Mittelalter. Nitra, 153-160.

Robak, Z. 2017b: The Origins and the Collapse of the Blatnica-Mikulčice Paradigm. Slovenská archeológia 65-1, 99-162.

Robak, Z. 2017c. Finds from the turn of the $8^{\text {th }}$ and $9^{\text {th }}$ centuries from bojná (Slovakia) and its agglomeration. In: Balogh, Cs. - Major, B. (eds): Conference of Young Scholars on the Migration Period. November 4-6, 2014, Volume 2, Esztergom, 203-215.

Robak, Z. 2019a: The Early Medieval stronghold Bojná-Valy - a seat of the elites or a garrison? In: Sudár, B. - Türk, A. (eds.): „Hadak Úján” A Nepvándorláskor Fiatal Kutatóinak XXIX. Konferenciája. 29 ${ }^{\text {th }}$ Conference Of Young Scholars on the Migration Period, November 15-16, Budapest 2019, 110-111.

Robak, Z 2019b: The Age of Migrating Ideas : A Short Contribution on Cruciform Decorations on Great Moravian Strap Fittings in the $9^{\text {th }}$ Century. In: Bewaffnung und Reiterausrüstung des 8. bis 10. Jahrhunderts in Mitteleuropa: Internationale Tagungen in Mikulčice IX, Brno, 453-477.

Ruttkay, A. 1976: Waffen und Reiterausfüstung des 9. bis zur ersten hälfte des 14. Jahrhunderts in der Slowakei (II). Slovenska archeológia 24-2, 245-395.

Ruttkay, M. 2012: Mocenské centrá Nitrianskeho kniežatstva. In: Panis, B. - Ruttkay, M. -Turčan, V. (eds.): Bratia, ktorí menili svet - Konštantín a Metod. Bratislava, 115-144.

Schránil, J. 1925: Několik prŕíspěvků k poznání kulturních proudů v zemích českých v X. a XI. věku. Obzor prehistorický - Niederlův sborník 4, 160-193.

Sieklicki, J. 1962: Quidam Priwina. Slavia Occidentalis 22, 115-146.

Sieklicki, J. 1967: „Privina exulatus“. Pamietjmol Słowiański 17, 161-165.

Sklenár, K. 1985: Původní zpráva o výzkumu slovanské knížecí mohyly u Želének v roce 1850. Časopis národního muzea, řada historická 154, 61-81.

Skutil, J. 1990: Obraz českých zemí ve franckých análech ze 7. do poloviny 9. století. Sborník prací filozofické fakulty Brněnské univerzity D 36-37, 47-55.

Sláma, J. 2006: Kosmovy záměrné omyly. In: Klápště, J. (ed.): Na prahu poznání českých dějin : Sborník prací k poctě 
Jiř́ho Slámy. Praha, 207-212.

Smetánka, Z. - Hrdlička, L. - Blajerová, M. 1973: Výzkum slovanského pohřebiště za Jízdárnou Pražského hradu v roce 1973. Archeologické rozhledy 26, 386-405, 433-438.

Staña, Č 2006: Velkomoravská pohřebiště v Rajhradě a Rajhradicích. Brno.

Staššíková-Štukovská (1996) 1997: Problematika vybraných typov veligradských (byzantsko-orientálnych) náušníc Vel’kej Moravy z pohl’adu doterajších výsledov výskumu v Borovciach. In: Marsina, R. - Ruttkay, A. (zost.): Svätopluk 894-1994. Nitra, 197-206.

Staššíková-Štukovská et al. 2006: Včasnostredoveké hradisko I. Spišské Tomášovce - Smižany - 1. etapa spracovania. Zborník SNM, Archeológia 16, 187-234.

Steinbübel, J. 1999: Nitra a Pribinovo kniežacie sídlo. In: Marsina, R. (ed.): Nitra v slovenských dejinách. Nitra, 50-55.

Steinbübel, J. 2016: Nitrianske kniežatstvo. Počiatky stredovekého Slovenska. Bratislava.

Stein, F. 1967: Adelsgräber des achten Jahrhunderts in Deutschland. Text und Tafeln. Berlin.

Steuer, H. 1968: Bewaffung und Sozialstruktur der Merowingerzeit. Nachrichten aus Niedersachsens Urgeschichte $37,18-7$.

Szőkee, B. M. 2010: Mosarburg/Zalavár und Pannonien in der Karolingerziet. Antaeus 31-32, 9-52.

Sző́ke, B. M. 2014: Mosaburg/Zalavár. In: Kouřil, P. (ed.): Great Moravia and the Beginnings of Christianity. Brno, 262-267.

Szókee, B. M. 2017: Priwina in Nitra und Mosaburg. In: Fusek, G. (ed.): Archäologische Studien zum frühen Mittelalter. Nitra, 175-192.

Šalkouský, P. 2015: Včasnostredoveké hradiská - hrady na Slovensku, Morave a v Čechách, In: Jenčík, P. - Struhár, V. (zost.): Hradiská - svedkovia dávnych čias. Dolná Mariková, 83-100.

Šolle, M. 1966: Stará Kouřim a projevy velkomoravské hmotné kultury v Čechách. Praha.

Stefan, I. 2011: Great Moravia, Statehood and Archaeology. The 'Decline and Fall' of One Early Medieval Polity. In: Macháček, J. - Ungerman, Š. (eds.): Frühgeschichtliche Zentralorte in Mitteleuropa. Bonn, 141-176.

Štefanovičová, T. 1975: Bratislavský hrad v 9. - 12. storočí. Bratislava.

Štefanovičová, T. 1989: Osudy starých Slovanov. Bratislava.

Štefanovičová, T. 1990: Schmuck des Nitraer Typs und seine Beziehungen zu Südosteuropa im 9. Jahrundert. A. Wosinsky Mór múzeum évkönyve 15, 215-230.

Štefanovičová, T. 2005: Zur Frage der Elite der großmährischen Gesellschaft im Lichte der Funde aus der Slowakei. In: P. Kouřil ed., Die frühmittelalterliche Elite bei den Völkern des östlichen Mitteleuropas, Spisy Archeologického ústavu AV ČR Brno 25, Brno: Archeologický ústav AV ČR Brno, 255-270. 
Štih, P. 1994: Priwina: slawischer Fürst oder fränkischer Gräf? In: Brunner, K. - Merta, B. (eds.): Ethnogenese und Überlieferung. Angewamdte Methoden der Frühmittelalterforschung. Wien, 209-222.

Takács, M. 2018: How long indeed was the Ninth century AD in the Carpathian basin and the adjacent territories? Conclusions of a conference. Antaeus 35-36, 363-371.

Toř̌ke, A. 1968a: Slawisch - awarisches Gräberfeld in Holiare. Bratislava.

Toč́k, A. 1971: Flachgräberfelder aus dem IX. und X. Jahrhundert in der Südwestslowakei (I). Slovenská archeológia 19, 135-276.

Tomková, K. a kol. 2012: Levý Hradec v zrcadle archeologických výzkumů. Pohřebiště díl I, Praha.

Třestík, D. 1968: Kosmova kronika : Studie k počátkům českého dějepisectvá a politického myšlení. Praha.

Třestík D. 1991: Kdy zanikla Velká Morava? Studia Mediaevalia Pragensia II, 9-27.

Třestík, D. 1998: Grossmähren, Passau und die Ungarn um das Jahr 900: Zu den neuen Zweifeln an der Authentizität des Briefes der bayerischen Bischöfe an Papst Johann IX. aus dem Jahr 900. Byzantinoslavica. Revue internationale des études byzantines 59-1, 137-160.

Tréstíke, D. 1999: Místo Velké Moravy v dějinách. Ke stavu a potřebám bádání o Velké Moravě. Český časopis historický 97, č. 4, 689-727.

Třšctík, D. 2000: „Veliké město Slovanů jménem Praha“. Státy a otroci ve střední Evropě v 10. století. In: Polanský, L. et al. (eds.): Přemyslovský stát kolem roku 1000. Praha, 49-70.

Třestík, D. 2001: Vznik Velké Moravy: Moravané, Čechové a střední Evropa v letech 791-871. Praha.

Ungerman, Š. 2005: Ženský šperk staršího velkomoravského horizontu. Archeologické rozhledy 57, 707-749.

Ungerman, Š. 2011: Tzv. blatnicko-mikulčický horizont a jeho vliv na chronologii raného středověku. In: Karolínska kultúra a Slovensko. Zborník Slovenského národného múzea, Archeológia. Supplementum 4. Bratislava, 135148.

Ungerman, Š. 2018: Vznik honosného velkomoravského šperku. Stav výzkumu a jeho perspektivy. In: Gedoga, B. - Grossman, A. - Piotrowski, W. (Hrsg.): Inspirationen und Funktion der Ur-und Frühgeschichtliche Kunst. Biskupin - Wrocław, 509-530.

Ungerman, Š. 2019: Die Wadenriemengarnituren im frühmittelalterlichen Mähren. In: Bewaffnung und Reiterausrüstung des 8. bis 10. Jahrhunderts in Mitteleuropa : Internationale Tagungen in Mikulčice IX, Brno, 307-341.

Vavřnek. 2013: Cyril a Metoděj mezi Konstantinopolí a Římem.Kniha vychází u př́ležitosti 1150. výročí prí́chodu „soluňských bratřri“ na Velkou Moravu. Praha.

Vendtová, V. 1969: Slovanské osídlenie Pobedima a okolia. Slovenská archeológia 17-1, 119-232.

Werner, J. 1978/1979: Zur Zeitstellung der altkroatischen Grabfunde von Biskupi-Crkvina (Marienkirche). Schild von Steier 15/16, 1978/1979 (Festschrift Modrijan), 227-237. 
Widajewič, 1947: Państwo Wiślan. Krakow.

Wiboda, M. 2010: Morava v době knížecí 906 - 1197. Praha.

Wihoda, M. 2014: Od Moravanů k Velké Moravě a zase zpět. In: Kouřil, P. (ed.). Velká Morava a počátky křest’anství. Brno, 46-50.

Wihoda, M. 2019: The Second Life of the Mojmirid Dukes. In: Macháček, J. - Wihoda, M. (eds.): The Fall of Great Moravia. Who Was Buried in Grave H153 at Pohansko near Břeclav. Leiden, Boston. 94-109.

Wolfram, H. 1995: Salzburg, Bayern und Österreich. Die Conversio Bagoariorum et Carantanorum und die Quellen ihrer Zeit. Wien; München.

Wolfram, H. 2012: Conversio Bagoariorum et Carantanorum. Das Weißbuch der Salzburger Kirche über die erfolgreiche Mission in Karantanien und Pannonien mit Zusätzen und Ergänzungen. Ljubljana.

Wood, S. 2006: The Proprietary Church in the Medieval West. Oxford.

Zavadil, O. 2007: Dopis markrabího Ariba králi Arnulfovi. Mediaevalia Historica Bohemica 11, 7-21.

Žemlička, J. 1997: Čechy v době knížeci $(1034-1198)$. Praha.

\section{Summary}

The archaeological research of early medieval jewelry from Central Danube region, formerly known as byzantine-oriental and later veligrad type, has significantly developed during the last two decades. Recent scholarship has notably changed the older relative and absolute chronology. By comparing the collections of jewelry founds from the burial sites it is possible to distinguish three development phases (horizons) of the woman luxurious jewelry. The oldest types are influenced by the traditions of jewelry from the Avarian and Byzantine cultural sphere. For now, the aforesaid horizon is primarily represented at the burial sites from agglomeration Staré Město - Uherské hradište. The second and third phases constitute significantly different forms of earrings and „gombiks“ (buttons) which are mostly located in the territory of southern Morava; it can be described as a new wave of jewelry. The collections of findings classified as the new wave are common in the other important Moravian centers from $9^{\text {th }}$ century, notably in Mikulčice, Břeclav - Pohansko, and also in the central sites from Bohemia like Praha - Lumbeho zahrada, Stará Kouřim and from western Slovakia in Bína, Ducové, and few others. However, the comparative analysis of luxurious jewelry spatial distribution shows that while at the Moravia and in the Bohemia we can identify more findings belonging to a older phase of the new wave, in the region of the so-called Principality of Nitra (western and central Slovakia) we mostly observe the last phase (the younger new wave) of jewels. Furthermore, up to the present, there are registered considerably smaller quantities of luxurious artifacts from the archeological localities associated with the Principality of Nitra. Besides, in contrast to the archeological sites from $9^{\text {th }}$ century Moravia and Bohemia, one can notice also a complete absence of the rich child graves. There are several differences between sites from the territory of Nitra and those belonging to Morava and Bohemia. Apart from the lower frequency of woman and child graves with luxurious jewelry, there is also disparity in the presence of graves with spurs. The child graves with spurs have been not yet identified in the supposed territories of Nitra principality. The smaller distribution of these artifacts connected to social elite opens up the question of the position of the so-called Principality of Nitra within the political unit traditionally denoted as Great Moravia.

Apart from the conventional historiographic explanation, the new reading of the well-known textual evidence does not confirm the incorporation of the territory of Nitra into (Great) Moravian principality after the expulsion of 
Pribina around the year 833 . On the contrary, the textual analysis of the available written sources indicates that the formation of the wider territorial unit with the center in Nitra may have occurred as a consequence of the expansion of Moravian prince Svätopluk in the second half of the $9^{\text {th }}$ century. The almost contemporary source, the Theotmarbrief, provides direct information about the Svatopluk's military subjugation of the territory which became the newly founded diocese of Wiching. Furthermore, two different traditions recorded in the chronicles from high Middle Ages (Chronica Boemorum from Cosmas, Gesta Hungarorum from Anonymous) preserved the information about Svätopluk territorial gain of the region between rivers Váh, Hron and Dunaj. The more accurate specification of the Svatopluk's eventual subjugation of the territory of Nitra remains an open question. The lower concentration of archaeological findings of (not only) luxury jewelry in western Slovakia does not currently confirm the presence of the rich elite in the first half of the $9^{\text {th }}$ century, but rather indicates the lower complexity of the political organization and social stratification in the area when compared to the regions near south Moravia, and even in middle Bohemia. Some manifestations of material culture were probably adopted in the eastern regions of the Middle Danube only during the second half of the $9^{\text {th }}$ century. Eventually, the reason of considerable qualitative and quantitative discrepancy between the archeological evidence from the „two centers“ of the so-called Great Moravia could be possibly explained by the later incorporation of the western and middle Slovakia territories to the political unit governed by Mojmirids - decades later than is usually assumed. 